\title{
Impact of halide additives on green antisolvent and high- humidity processed perovskite solar cells
}

DOI:

10.1016/j.apsusc.2020.147949

\section{Document Version}

Accepted author manuscript

Link to publication record in Manchester Research Explorer

\section{Citation for published version (APA):}

Chen, Q., Ke, J. C. R., Wang, D., Mokhtar, M. Z., Thomas, A. G., \& Liu, Z. (2021). Impact of halide additives on green antisolvent and high-humidity processed perovskite solar cells. Applied Surface Science, 536, [147949]. https://doi.org/10.1016/j.apsusc.2020.147949

\section{Published in:}

Applied Surface Science

\section{Citing this paper}

Please note that where the full-text provided on Manchester Research Explorer is the Author Accepted Manuscript or Proof version this may differ from the final Published version. If citing, it is advised that you check and use the publisher's definitive version.

\section{General rights}

Copyright and moral rights for the publications made accessible in the Research Explorer are retained by the authors and/or other copyright owners and it is a condition of accessing publications that users recognise and abide by the legal requirements associated with these rights.

\section{Takedown policy}

If you believe that this document breaches copyright please refer to the University of Manchester's Takedown Procedures [http://man.ac.uk/04Y6Bo] or contact uml.scholarlycommunications@manchester.ac.uk providing relevant details, so we can investigate your claim.

\section{OPEN ACCESS}




\title{
Impact of Halide Additives on Green Antisolvent and High-Humidity Processed Perovskite Solar Cells
}

Qian Chen $^{a,}{ }^{*}$, Jack Chun-Ren Ke ${ }^{a, b}$, Dong Wang ${ }^{a}$, Muhamad Z. Mokhtar ${ }^{a}$, Andrew G. Thomas $^{a, b}$, Zhu Liu ${ }^{a}$ *

${ }^{a}$ Department of Materials, The University of Manchester, Oxford Road, Manchester, M13 9PL, UK

${ }^{\mathrm{b}}$ Photon Science Institute, The University of Manchester, Oxford Road, Manchester, M13 9PL, UK

* Corresponding author.

E-mail address: qian.chen-2@manchester.ac.uk, zhu.liu@manchester.ac.uk

\begin{abstract}
Organometal halide perovskites have recently gained remarkable interest as a light absorber for photovoltaic technology. However, the majority of efficient perovskite solar cells (PSCs) are fabricated in the glovebox. From the mass production perspective, it is vital to improve the quality of ambient-processed perovskite, as well as to reduce health risks, costs, and complexity of fabrication. This study investigates the effect of using green antisolvent ethyl acetate with various halide additives on the performance of ambient-processed planar PSCs by a one-step deposition method, under a high relative humidity $(\mathrm{RH})$ of 50-60\%. Differences in microstructures, crystallinity, surface chemistry and optoelectronic properties for the green antisolvent and ambient-processed perovskite films with the addition of $\mathrm{PbCl}_{2}, \mathrm{PbBr}_{2}$, and $\mathrm{MAI}$ are observed, compared to the pristine film. Ambient-processed perovskite films with $\mathrm{PbCl}_{2}$ addition remarkably improves the PCE of the pristine device by $17.3 \%$ and achieves a fill factor up to $76.3 \%$. Addition of $\mathrm{PbCl}_{2}$ also enhances the stability of the devices and retains $81 \%$ of their initial PCEs after storage in ambient air for 28 days. These findings provide a strategy of using halide additives and green antisolvent for the fabrication of high-quality perovskite films under high relative humidity without the need of glovebox.
\end{abstract}

Keywords: green antisolvent; ambient-processed; planar perovskite solar cells; halide additives; long-term stability 


\section{Introduction}

Organometal halide perovskites with an $\mathrm{ABX}_{3}$ crystal structure have attracted great attention in the photovoltaic (PV) field, ascribed to their superb optoelectronic properties such as high absorption coefficients, long carrier diffusion length, high carrier mobilities, and low exciton binding energy [1-5]. Within only a decade of research, the power conversion efficiencies (PCE) of perovskite solar cells (PSCs) have rapidly increased from 3.8\% to 25.2\% [6]. Despite the rapid development of this emerging PV technology, PSCs are known to be sensitive to moisture and oxygen in both fabrication and operation processes [1,7]. Therefore, in most cases, highly efficient laboratory-scale PSCs are mainly fabricated in a nitrogen-filled glovebox or controlled atmosphere [8]. In order to reduce the costs and complexity of fabrication for the industrialization of PSCs, there is a need to develop facile methods for the fabrication of highquality perovskite films in ambient air [1,9].

The influence of the environmental humidity during the formation of the perovskite film is still under debate $[1,10,11]$. At the early stage of the PSCs research, it was believed that $\mathrm{N}_{2}$-filled glovebox with a low level of moisture and oxygen has to be used in order to fabricate efficient PSCs due to the loss of the organic cation in the perovskite under the ambient condition $[1,7]$. Later on, some studies suggested that a controlled relative humidity $(\mathrm{RH})$ of around $20-35 \%$ can improve the crystallinity of the perovskite films, resulting in an increase of the device PCE [11-13]. However, several studies suggested that the moisture in ambient air can be detrimental to the device PCE when the $\mathrm{RH}>40 \%$ [14]. For instance, Yang et al. fabricated $\mathrm{CH}_{3} \mathrm{NH}_{3} \mathrm{PbI}_{\mathrm{X} C l}-\mathrm{X}$ based PSCs in a glove box or with a controlled $\mathrm{RH}$ of $15-20 \%$ achieved the device PCE of $11.32 \%$ or $10.71 \%$, respectively [15]. However, the device PCE dropped to only $4.07 \%$ or $0.53 \%$ when the perovskite films were fabricated under a RH of $40-50 \%$ or $60-70 \%$, due to poor coverage of the perovskite films on the substrate. Li et al. obtained similar results, and they found that the device PCE was significantly reduced when the RH $>40 \%$ for both onestep and two-step deposition processes [16]. 
To date, several strategies have been established to fabricate the highly efficient PSCs in ambient air under different RH. Su et al. employed hot air blowing to spray-coating the $\mathrm{CH}_{3} \mathrm{NH}_{3} \mathrm{PbI}_{\mathrm{X}} \mathrm{Cl}_{3}-\mathrm{X}$ for ambient-processed PSCs at $\mathrm{RH}<30 \%$ and achieved a PCE of $13.5 \%$ [17]. Liu et al. used 4-tert-butylpyridine (tBP) as the additive to form a hydrophobic layer on the surface of perovskite film to improve the PCE of ambient-processed PSCs by a two-step process and achieved the PCE of $12.62 \%$ and $10.88 \%$ at RH of $40-50 \%$ and $50-60 \%$ [18]. Tai et al. used $\mathrm{Pb}(\mathrm{SCN})_{2}$ as the lead precursor to fabricate $\mathrm{CH}_{3} \mathrm{NH}_{3} \mathrm{PbI}_{3-\mathrm{x}}(\mathrm{SCN})_{\mathrm{x}}$ film by a two-step process and achieved a device PCE of $15.12 \%$ for the mesoscopic PSCs fabricated at RH>70\% [19]. Guo et al. also used a two-step process to deposit $\mathrm{CH}_{3} \mathrm{NH}_{3} \mathrm{PbI}_{3}$ with $\mathrm{ZnO}$ as the electron transport layer and archives a PCE of $14.25 \%$ at $50 \%$ RH [20]. Cheng et al. demonstrated a preheating technique of the substrate and $\mathrm{PbI}_{2}$ solution with a two-step process and achieved a device PCE up to $18.11 \%$ [10]. However, they found that it was challenging to prepare the highquality perovskite film by a one-step process due to the uncontrollable and rapid crystallization process of the film in ambient air [10].

One-step deposition of the perovskite film, as a simple and straightforward method, has the potential to be developed for future roll-to-roll and cost-effective fabrication of PSCs, in conjunction with the use of antisolvent bath $[14,21,22]$. The use of appropriate antisolvent plays a vital role in controlling the morphology during the crystallization of the perovskite films in ambient air $[9,22]$. Several studies have utilized different types of antisolvents with the onestep deposition process to fabricate efficient PSCs in ambient air. Gedamu et al. used a mixed solvent-antisolvent with $75 \%$ chlorobenzene (CL) and $25 \%$ ethanol to fabricate $\mathrm{CH}_{3} \mathrm{NH}_{3} \mathrm{PbI}_{\mathrm{XCl}} \mathrm{Cl}_{3-\mathrm{X}}$ based PSCs and achieved a PCE of $14.0 \%$ at $40 \% \mathrm{RH}$ [23]. Yang et al. added methanol into diethyl ether (DE) as the antisolvent to treat perovskite film and achieves a PCE of $16.4 \%$ at $50 \%$ RH [24]. Sveinbjörnsson et al. used CL as the antisolvent to fabricate $\left(\mathrm{FAPbI}_{3}\right)_{1-\mathrm{x}}\left(\mathrm{MAPbBr}_{3}\right)_{\mathrm{x}}$ for mesoscopic PSCs and achieved a PCE up to $18.8 \%$ at $50 \% \mathrm{RH}$ [25]. Recently, Troughton et al. used ethyl acetate (EA) as antisolvent to treat the $\mathrm{CH}_{3} \mathrm{NH}_{3} \mathrm{PbI}_{3}$ 
film and achieved an optimized PCE of $14.5 \%$ and $15.0 \%$ for inverted and mesoscopic PSCs at $75 \% \mathrm{RH}$ [9]. They found that EA is able to absorb a significant volume of moisture in comparison to antisolvents such as toluene, thus may protect the perovskite intermediate phase MAI-PbI 2 -DMSO during the spin-coating process from airborne moisture [9].

A critical issue that needs to be addressed is the potential risk of using these antisolvents on humans and environment since they are volatile during the deposition process, especially for the ambient or scalable fabrication process [26]. CL or toluene (TL) are antisolvents with a low threshold limit value (TLV), which are potentially harmful to humans and environment for ambient and mass production [27]. Compared to CL and TL, DE is considered to be safer to use due to its much higher TLV [27]. However, there is still potential health risks to human for heavy and long-term exposure to DE [27]. EA is recognized as a green antisolvent with a high TLV, which is less hazardous and less flammable than DE [28]. Therefore, EA can be a promising green antisolvent for future ambient and scalable production of PSCs.

To date, several studies have used the chloride or bromide salts as the halide additives or lead precursors to improve the PCE and stability of the PSCs, with the majority of the studies carried out in the inert environment [4,29-31]. However, the impact of these halide additives on the nucleation of the perovskite films with the use of EA as the antisolvent in ambient conditions is not well understood. Herein, we systematically investigate the impact of $\mathrm{PbCl}_{2}, \mathrm{PbBr}_{2}$, and MAI as additives on the one-step deposited perovskite films with EA as antisolvent, under a high RH of 50-60\%. We carry out a series of characterizations to understand the effect of these halide additives on the microstructure, crystallinity, surface chemistry, optoelectronic properties, PV performance, and long-term stability of the ambient-processed perovskite films and devices. We observe that the addition of $\mathrm{PbCl}_{2}$ enlarges the grain size, enhances the crystallinity and passivate the grain boundaries by the formation of $\mathrm{PbI}_{2}$. In complete planar PSCs, devices with $\mathrm{PbCl}_{2}$ addition achieve a champion PCE of $16.20 \%$, in comparison to the standard $\mathrm{CH}_{3} \mathrm{NH}_{3} \mathrm{PbI}_{3}$ with a champion $\mathrm{PCE}$ of $13.81 \%$. In addition, devices with $\mathrm{PbCl}_{2}$ retain 
$81 \%$ of their initial PCEs after storage in air for 28 days. The addition of $\mathrm{PbBr}_{2}$ also enlarges the grain size of perovskite crystals and gives the least hysteresis behavior of the PSCs. The addition of excess MAI in this study shows a negative impact on the PV performance of the ambient-processed PSCs.

\section{Result and discussion}

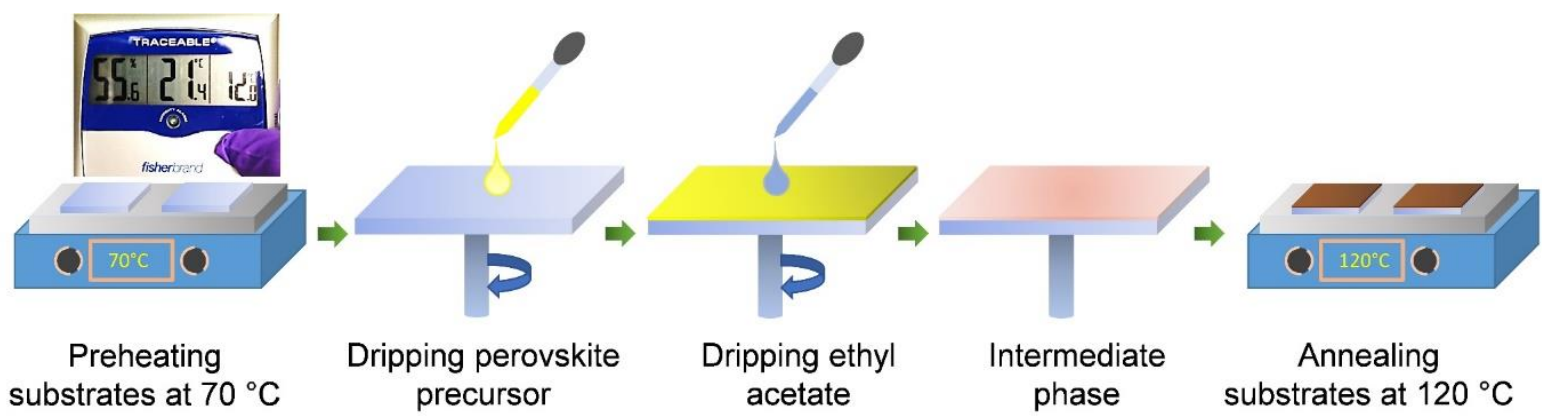

Fig. 1 Schematic representation of the one-step spin-coating process of perovskite film with ethyl acetate as the antisolvent in ambient air with a humidity meter showing a relative humidity of $55.6 \%$.

Apart from the thermal evaporation of gold electrodes, all fabrication processes are carried out in ambient conditions under $\mathrm{RH}$ of $50-60 \%$. The deposition of the perovskite films is presented in Fig. 1. We prepare a compact $\mathrm{TiO}_{2}$ layer on top of an indium tin oxide (ITO) coated glass and then preheat the substrates to $70{ }^{\circ} \mathrm{C}$ before deposition of the perovskite film. A standard stoichiometric precursor with the molar ration of $\mathrm{PbI}_{2}: \mathrm{MAI}=1: 1$ is used to form the pristine perovskite film. We then add ethyl acetate dropwise during the spin-coating process of the perovskite precursor and eventually anneal the substrate at $120{ }^{\circ} \mathrm{C}$ to evaporate the residual solvent and form a crystalline perovskite film. The detailed fabrication process is explained in the Experimental Section. To introduce the additives, we add $\mathrm{PbCl}_{2}, \mathrm{PbBr}_{2}$ or MAI to the perovskite precursor to investigate their impact through a series of characterizations.

We first perform scanning electron microscopy (SEM) with in-lens detector to understand the impact of adding $\mathrm{PbCl}_{2}, \mathrm{PbBr}_{2}$ or MAI upon the microstructures of the perovskite films. In Fig. 
2 and S1, the images show the surface microstructure of pristine perovskite film in comparison to the films with different additives. The pristine film shows an average grain size of $0.10 \mu \mathrm{m}^{2}$ with the largest grain size up to $0.42 \mu \mathrm{m}^{2}$, calculated based on Fig. S1a with the average size of 80 grains, as shown in Fig. S2a. The addition of excess MAI shows no significant change to the film morphology and gives an average grain size of $0.11 \mu \mathrm{m}^{2}$ (Fig S1b and S2b). The addition of both $\mathrm{PbCl}_{2}$ and $\mathrm{PbBr}_{2}$ significantly increases the average grain size to 0.26 (Fig S1c and S2c) and $0.17 \mu \mathrm{m}^{2}$ (Fig S1d and S2d), with the largest grain size up to 1.06 and $0.50 \mu \mathrm{m}^{2}$.
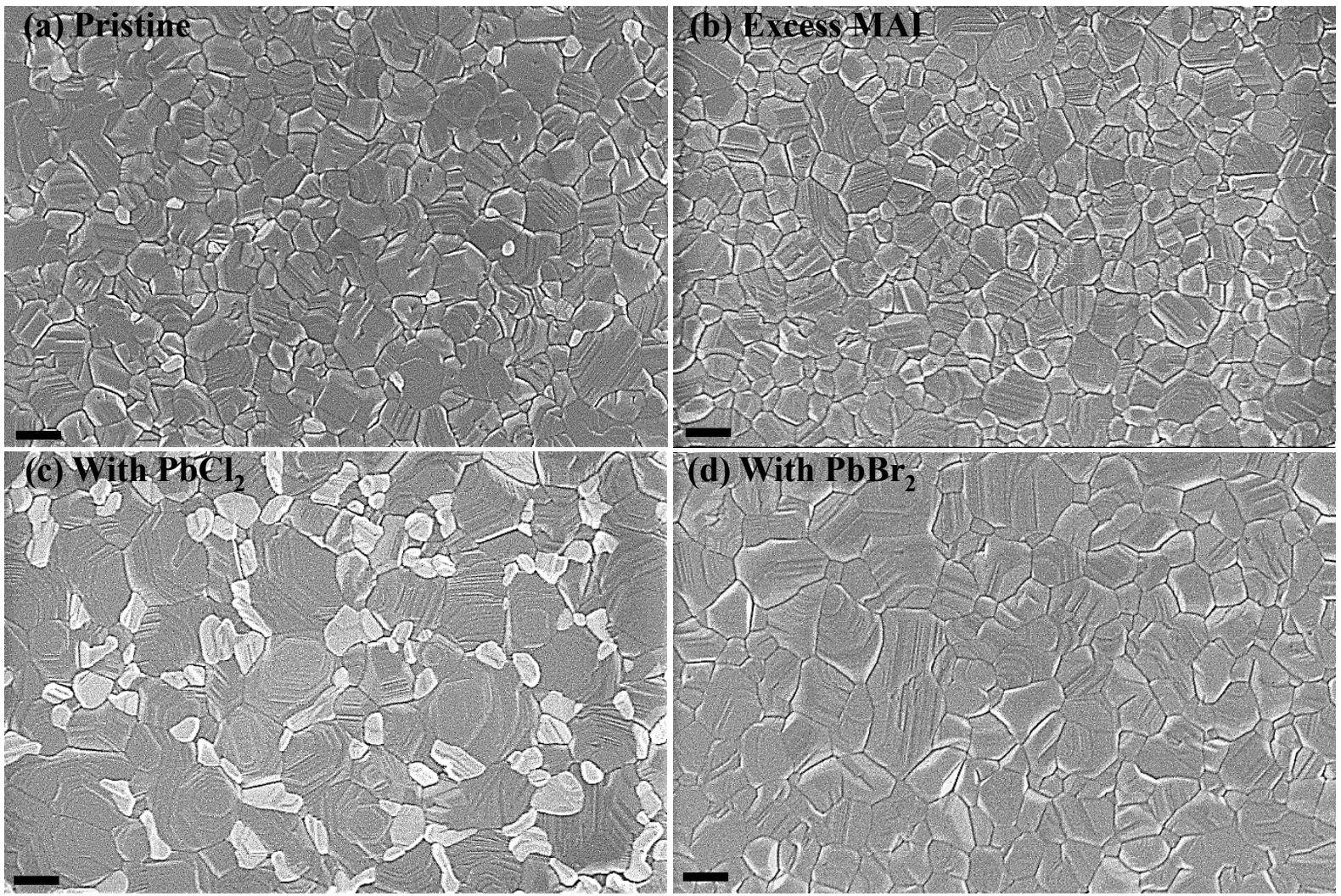

Fig. 2. SEM (50 KX magnification) images of the perovskite films (a) pristine, (b) excess

MAI, (c) with $\mathrm{PbCl}_{2}$ and (d) with $\mathrm{PbBr}_{2}$. (scale bar $=400 \mathrm{~nm}$ )

All ambient-processed films at RH of 50-60\% appear to be dense and uniform without obvious pinholes. These film morphologies are quite different compared to some previous studies on processing the $\mathrm{CH}_{3} \mathrm{NH}_{3} \mathrm{PbI}_{\mathbf{X}} \mathrm{Cl}_{3}-\mathrm{X}$ or $\mathrm{CH}_{3} \mathrm{NH}_{3} \mathrm{PbI}_{3}$ in ambient air at high $\mathrm{RH}[32,33]$. Gao et al. observed the morphologies of $\mathrm{CH}_{3} \mathrm{NH}_{3} \mathrm{PbI}_{\mathrm{X}} \mathrm{Cl}_{3-\mathrm{X}}$ and $\mathrm{CH}_{3} \mathrm{NH}_{3} \mathrm{PbI}_{3}$ films changed from dense to the island- or rod-shaped when they were deposited in ambient air at RH of $70 \%$ by a onestep process. The low coverage of the perovskite films brought a detrimental impact on the 
device's performance [32]. Wang et al. found that annealing $\mathrm{CH}_{3} \mathrm{NH}_{3} \mathrm{PbI}_{\mathrm{X}} \mathrm{Cl}_{3-\mathrm{X}}$ in ambient air at $\mathrm{RH}>50 \%$ induced large gaps between the perovskite grains and gave a PCE of $9.2 \%$ compared to the dense perovskite film annealed in a vacuum with a PCE of $12.98 \%$ [33]. Therefore, perovskite film with a denser and more uniform morphology may contribute to better photovoltaic performance according to the previous studies [32,33].

We note that the large perovskite grains are surrounded by some smaller and brighter grains for the film with $\mathrm{PbCl}_{2}$. These smaller grains may be ascribed to $\mathrm{PbI}_{2}$ or $\mathrm{PbI}_{2}$-rich grains due to their larger bandgap and reduced conductivity, resulting in more charging of the electrons and brightness in the image [34]. However, this is not found in the film with $\mathrm{PbBr}_{2}$. The increase of the grain size by adding $\mathrm{PbCl}_{2}$ may be attributed to two reasons: (1) the accumulation of negatively charged $\mathrm{Cl}^{-}$at the grain boundaries and surface reduces the surface tension of the grain, thereby promoting the coalescence of the small grains [31]. (2) the formation of the $\mathrm{MAPbCl}_{3}$ intermediate phase acts as a template to improve the growth orientation and grain structure of the perovskite crystals [35].

We carry out X-ray diffraction (XRD) measurement to investigate the effect of different additives on the chemical composition and crystallinity of the ambient-processed perovskite, as presented in Fig. 3 and S3. The film with $\mathrm{PbCl}_{2}$ additive shows the $\mathrm{PbI}_{2}$ diffraction peak at 12.7 ${ }^{\circ}$, which may indicate that the brighter grains observed in Fig. 2c are $\mathrm{PbI}_{2}$ or $\mathrm{PbI}_{2}$-rich grains [34]. It has been pointed out that the existence of the $\mathrm{PbI}_{2}$ phase at the grain boundaries and interfaces could passivate the perovskite film, resulting in the reduction of the carrier recombination $[31,34]$. We also observe the $\mathrm{PbI}_{2}$ peak in the pristine film. Both films with the addition of $\mathrm{PbBr}_{2}$ and excess MAI, however, only show the pure perovskite crystals oriented at (110), (220) and (310) planes. The addition of $\mathrm{PbCl}_{2}$ or $\mathrm{PbBr}_{2}$ causes a shift of (110) planes towards higher $2 \theta$ (Fig. 3a), indicating the incorporation of the $\mathrm{Cl}^{-}$and $\mathrm{Br}^{-}$into the perovskite lattice, causing the shrinkage of the lattice due to the smaller ionic radii of the $\mathrm{Cl}^{-}$and $\mathrm{Br}^{-}$than $\mathrm{I}^{-}[31,36]$. It is noted that the peak intensity of (110) planes for the perovskite film with $\mathrm{PbCl}_{2}$ 
is three times higher than other films. We then calculate the crystal sizes of the pristine perovskite film and the films with the addition of $\mathrm{PbCl}_{2}, \mathrm{PbBr}_{2}$, and MAI by Scherrer equation, as shown in Table S1. Perovskite films with the addition of $\mathrm{PbCl}_{2}$ and $\mathrm{PbBr}_{2}$ exhibit the increase of the crystal size compared to that of the pristine film. This is in agreement with the SEM (Fig. 2) observation that the films with the addition of $\mathrm{PbCl}_{2}$ and $\mathrm{PbBr}_{2}$ show the larger grain size than the pristine film. These results indicate that the addition of $\mathrm{PbCl}_{2}$ effectively improves the crystallinity, enlarges the grain size and promotes a preferred growth orientation at the (110) planes.

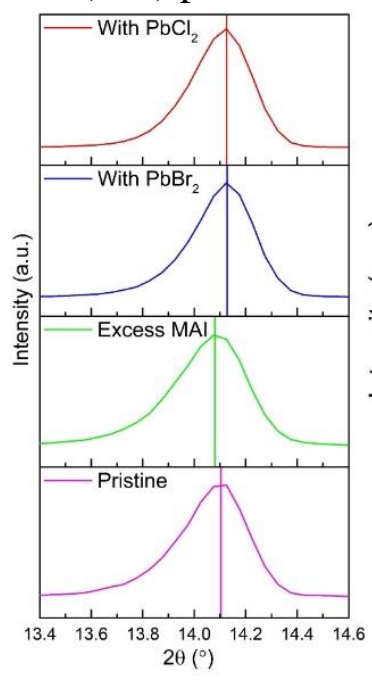

(a)

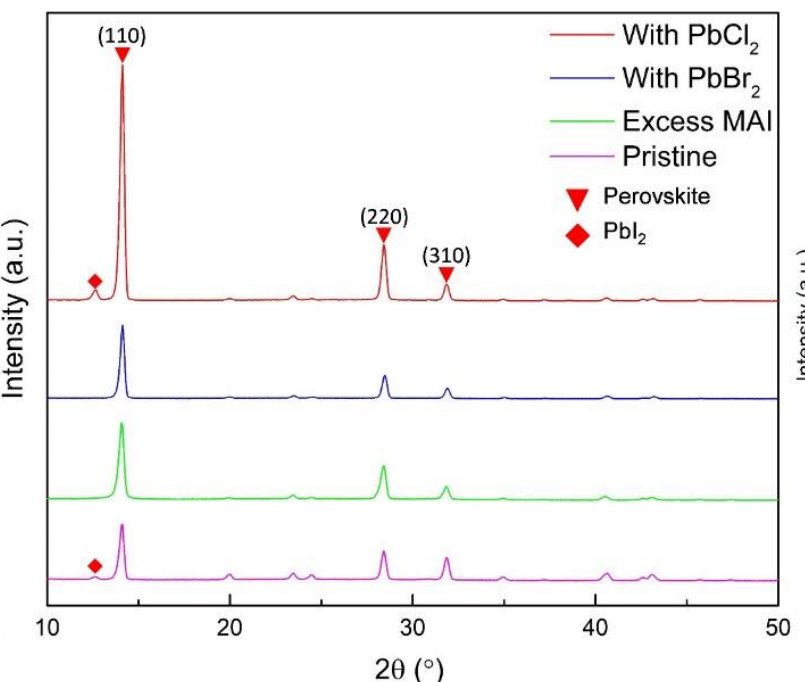

(b)

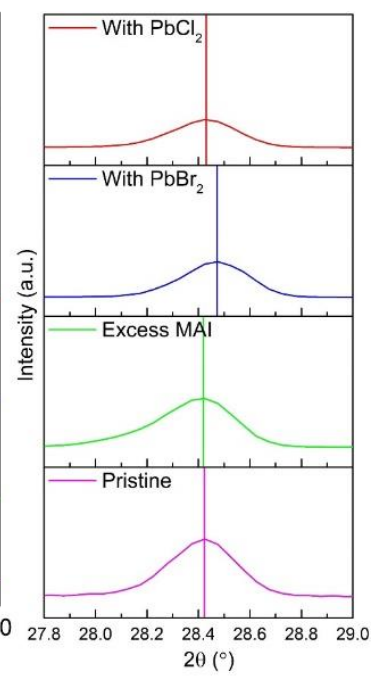

(c)

Fig. 3. XRD pattern of a pristine perovskite film and the perovskite films with the addition of $\mathrm{PbCl}_{2}, \mathrm{PbBr}_{2}$, and excess MAI in the $2 \theta$ range of (a) $13.4-14.6^{\circ}$, (b) $10-50^{\circ}$ and (c) $27.8-19.0^{\circ}$.

To investigate the surface chemistry of the perovskite with different additives, we performed X-ray photoelectron spectroscopy (XPS), as presented in Fig. 4 and Table S2. We observe that all the major $\mathrm{Pb} 4 \mathrm{f}_{7 / 2}$ peaks (denoted as $\mathrm{Pb}-\mathrm{I}$ ) are located at binding energies (BEs) of $138.6 \pm$ $0.1 \mathrm{eV}$, in agreement with the values for $\mathrm{CH}_{3} \mathrm{NH}_{3} \mathrm{PbI}_{3}$ perovskite in the literature $[7,37]$. Additional minor $\mathrm{Pb} 4 \mathrm{f}_{7 / 2}$ peaks (denoted as $\mathrm{Pb}-\mathrm{Pb}$ ) can be seen at $136.8 \pm 0.1 \mathrm{eV}$, indicating the presence of metallic lead $(\mathrm{Pb} 0)$ at the surface $[7,38]$. The $\mathrm{I} / \mathrm{Pb}$ value reveals the synchronous reduction of iodine and nitrogen relative to lead according to the standard stoichiometric values 
(3.0, respectively). Both the pristine $(2.6 \pm 0.1)$ and with the $\mathrm{PbCl}_{2}(2.7 \pm 0.1)$ films show lower $\mathrm{I} / \mathrm{Pb}$ values than the film with $\mathrm{PbBr}_{2}(2.8 \pm 0.1)$ and excess MAI $(2.9 \pm 0.1)$, suggesting that more $\mathrm{PbI}_{2}$ may exist on the surface of the film with $\mathrm{PbCl}_{2}$ and the pristine film. This finding further confirms the existence of $\mathrm{PbI}_{2}$ at the surface of the film with added $\mathrm{PbCl}_{2}$ and the pristine film, which is in good agreement with the results from the SEM and XRD characterizations.

(a)

(c)

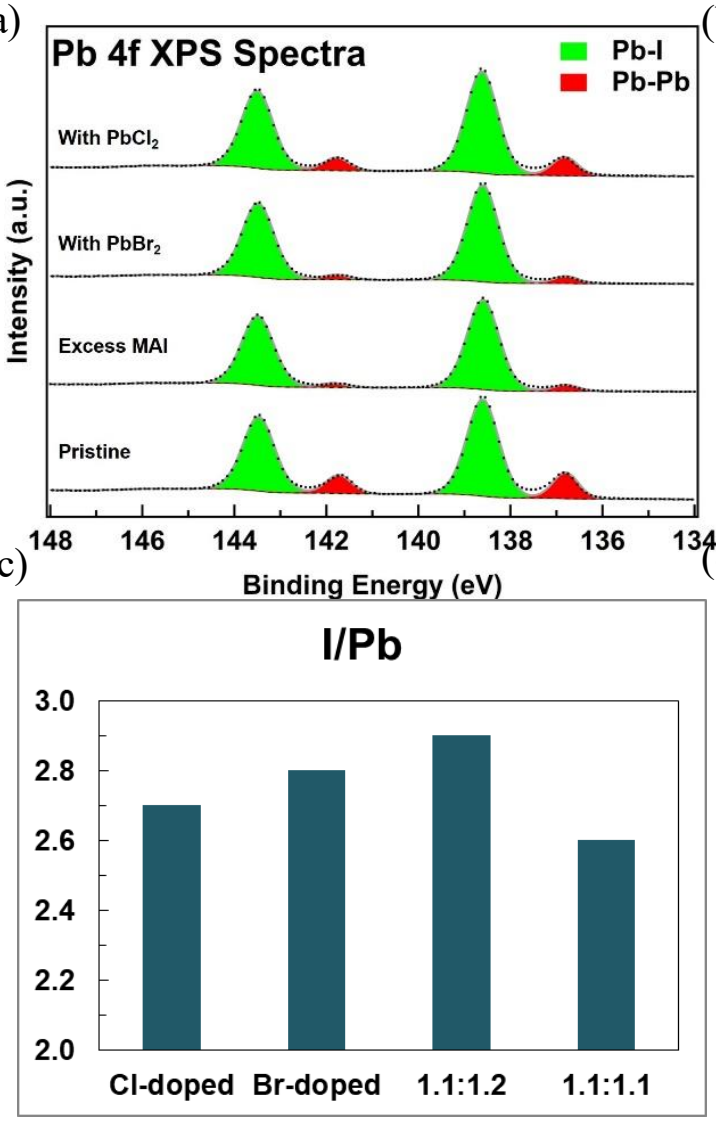

(b)
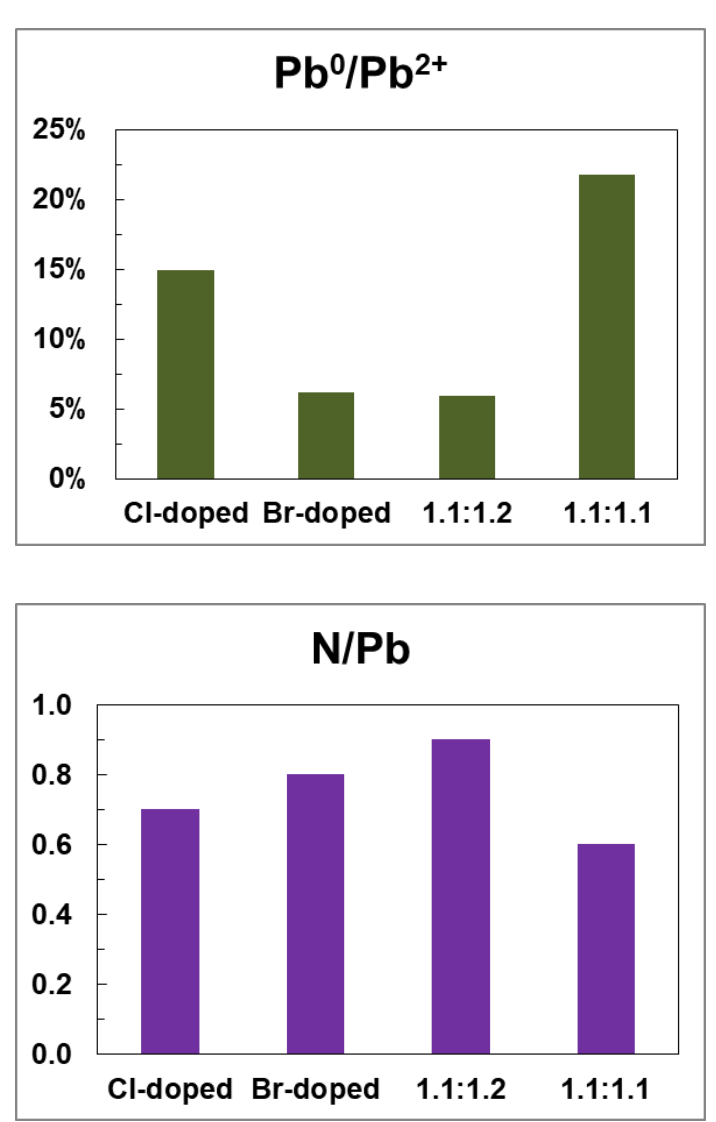

Fig. 4. (a) XPS spectra of a pristine perovskite film and the film with the addition of $\mathrm{PbCl}_{2}$, $\mathrm{PbBr}_{2}$ and excess MAI. Ratios of (b) $\mathrm{Pb}^{0} / \mathrm{Pb}^{2+}$, (c) $\mathrm{I} / \mathrm{Pb}$, and (d) N/Pb for various films determined by XPS. Note only $\mathrm{Pb}^{2+}$ is considered for the $\mathrm{Pb}$ in (c) and (d). To investigate the impact of different additives on the photovoltaic performance of the perovskite, we assembled planar perovskite solar cells with an architecture of ITOglass/TiO $/$ /perovskite/spiro-OMeTAD/Au. Previous studies have recognized that planar PSCs are more vulnerable to moisture during the perovskite deposition process than the mesoscopic PSCs $[12,14]$. This is because the use of mesoporous $\mathrm{TiO}_{2}$ helps to hold the perovskite in place 
during the spin-coating process and with thicker perovskite film to reduce the chance of short circuit $[12,14]$. Therefore, it is more challenging to fabricate efficient planar PSCs in ambient air under high RH. Fig. S4 shows an image of the actual devices after assembly. In Fig. 5 and S5, we present the typical current density voltage $(J-V)$ curves for the ambient-processed devices. The addition of $\mathrm{PbCl}_{2}$ achieves an average PCE of the PSCs to $15.21 \%$ and a champion device PCE of $16.20 \%$. The measured device PCE is relatively steady under the different scanning rates, as shown in Fig. S6. On the other hand, the pristine PSCs show an average shortcircuit current $\left(\mathrm{J}_{\mathrm{sc}}\right)$ of $18.53 \mathrm{~mA} \mathrm{~cm}^{-2}$, an average open-circuit voltage $\left(\mathrm{V}_{\mathrm{oc}}\right)$ of $1019.5 \mathrm{mV}$, an average fill factor (FF) of $71.7 \%$, yielding an average PCE of $13.53 \%$ with a champion device PCE of $13.81 \%$. We notice that the improvement of the PCEs by $\mathrm{PbCl}_{2}$ additive is contributed from enhanced $J_{s c}$ and FF.

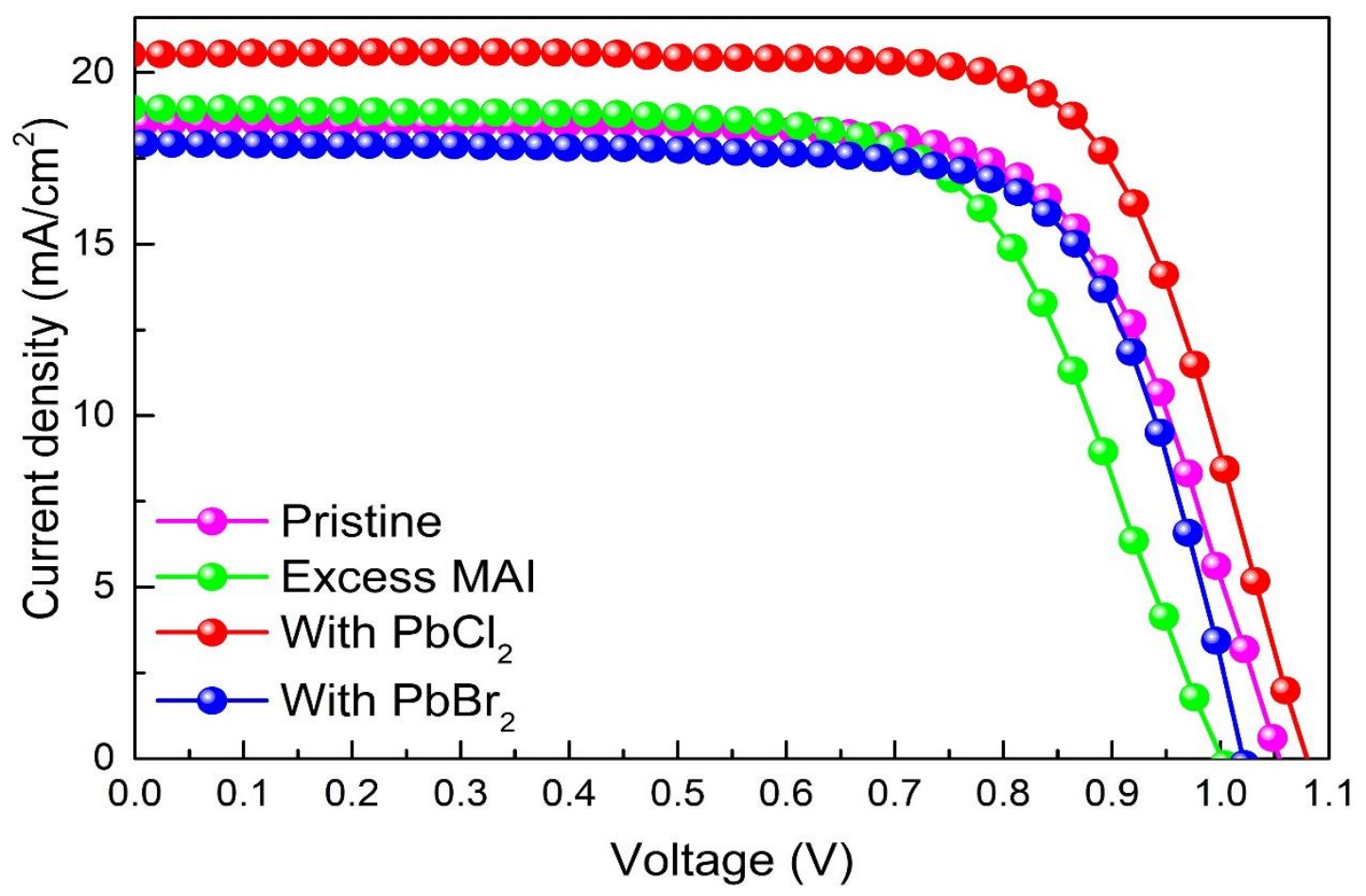

Fig. 5. Current density-voltage $(J-V)$ curves for the devices based on the pristine film and the films with the addition of $\mathrm{PbCl}_{2}, \mathrm{PbBr}_{2}$, and excess MAI measured from reverse scan (RS) under simulated AM1.5 sunlight measured at ambient air under RH of 50-60\%. 

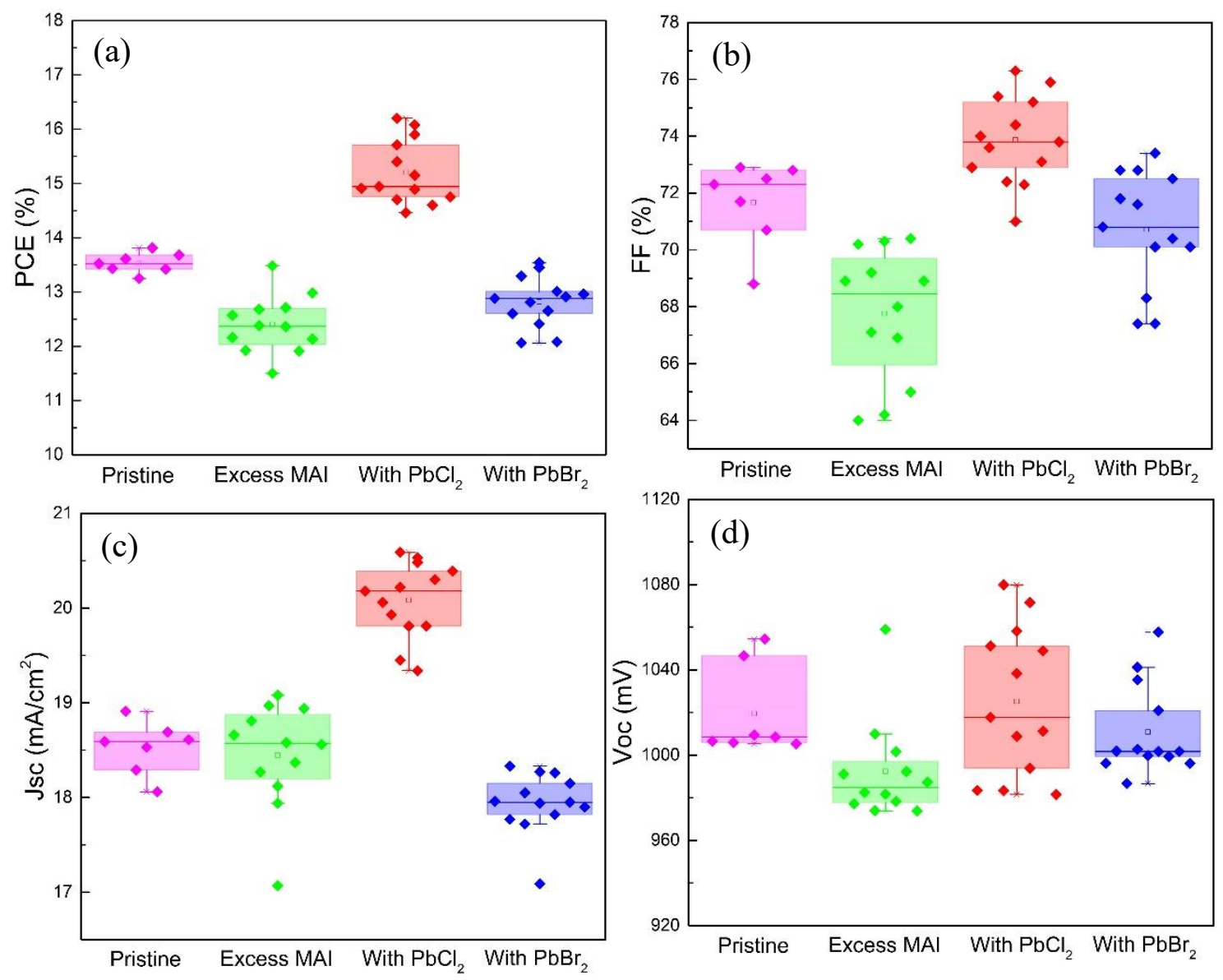

Fig. 6. Photovoltaic parameters distribution of (a) PCE, (b) FF, (c) $J_{s c}$ and (d) $V_{o c}$ for the ambient-processed devices with the pristine film and the films with excess $\mathrm{MAI}, \mathrm{PbCl}_{2}$ and $\mathrm{PbBr}_{2}$.

The distribution and a summary of the photovoltaic parameters based on the films with different additives are shown in Fig. 6 and Table S3. The enhanced device performance with $\mathrm{PbCl}_{2}$ additive can be mainly attributed to two reasons: (1) the improved crystallinity of the perovskite with the enlarged grain size; (2) the passivation of the grain boundaries and surfaces by the existence of $\mathrm{PbI}_{2}$ [39]. On the other hand, addition of $\mathrm{PbBr}_{2}$ to the films slightly reduces the photovoltaic performance, mainly due to the lower average $J_{S c}$ of $17.94 \mathrm{~mA} \mathrm{~cm}^{-2}$. Although addition of $\mathrm{PbBr}_{2}$ also enlarges the grain size of the perovskite film, it seems that the formation of $\mathrm{PbI}_{2}$ to passivate the film plays an important role in improving the device PCEs. Nonetheless, the device with $\mathrm{PbBr}_{2}$ additive does exhibit the lowest hysteresis index (HI) of $33.83 \%$ based on the equation (1) [40]: 


$$
H I=\frac{P C E_{R S}-P C E_{F S}}{P C E_{R S}} \times 100 \%
$$

Where $\mathrm{PCE}_{\mathrm{RS}}$ is the PCE measured in the reverse direction, and $\mathrm{PCE}_{\mathrm{FS}}$ is the PCE measured in the forward direction. It has been pointed out that partial replacement of $\mathrm{I}^{-}$by $\mathrm{Br}^{-}$could increase the $\mathrm{I}^{-}$migration activation energy due to the local structural distortion induced by the $\mathrm{Br}^{-}$ substitution, resulting in a decreased hysteresis behavior [5]. Excess MAI in the current study leads to the reduction of the photovoltaic performance mainly due to the lower average FF of $67.8 \%$ and average $V_{o c}$ of $992.4 \mathrm{mV}$. Nevertheless, according to other studies, it is found that the addition of a different amount of $\mathrm{PbBr}_{2}[41]$ and MAI [42,43] can enhance the device PCE. A summary of the photovoltaic performance of several recent ambient-processed PSCs compared that in the current work is given in Table $\mathbf{S 4}$.

To further understand why adding $\mathrm{PbCl}_{2}, \mathrm{PbBr}_{2}$ or excess MAI leads to differences in the photovoltaic performance of the devices; we perform ultraviolet-visible (UV-Vis) absorption spectroscopy and photoluminescence (PL) spectroscopy as shown in Fig. 7a and b. The addition of $\mathrm{PbCl}_{2}$ leads to an increase in the absorption over the wavelength range from 400 $500 \mathrm{~nm}$, possibly due to the enhanced crystallinity and enlarged grain size, in good agreement with the higher $J_{s c}$ of the PSCs. A stronger PL intensity in the film with the $\mathrm{PbCl}_{2}$ additive further confirms the passivation of the grain boundaries and surfaces by $\mathrm{PbI}_{2}$, which effectively reduces the nonradiative recombination in the film, resulting in improved photovoltaic performance [31]. The film with $\mathrm{PbBr}_{2}$ additive and excess MAI exhibits reduced light absorption and PL intensity, inconsistent with the decreased photovoltaic performance of the PCE measurement. 

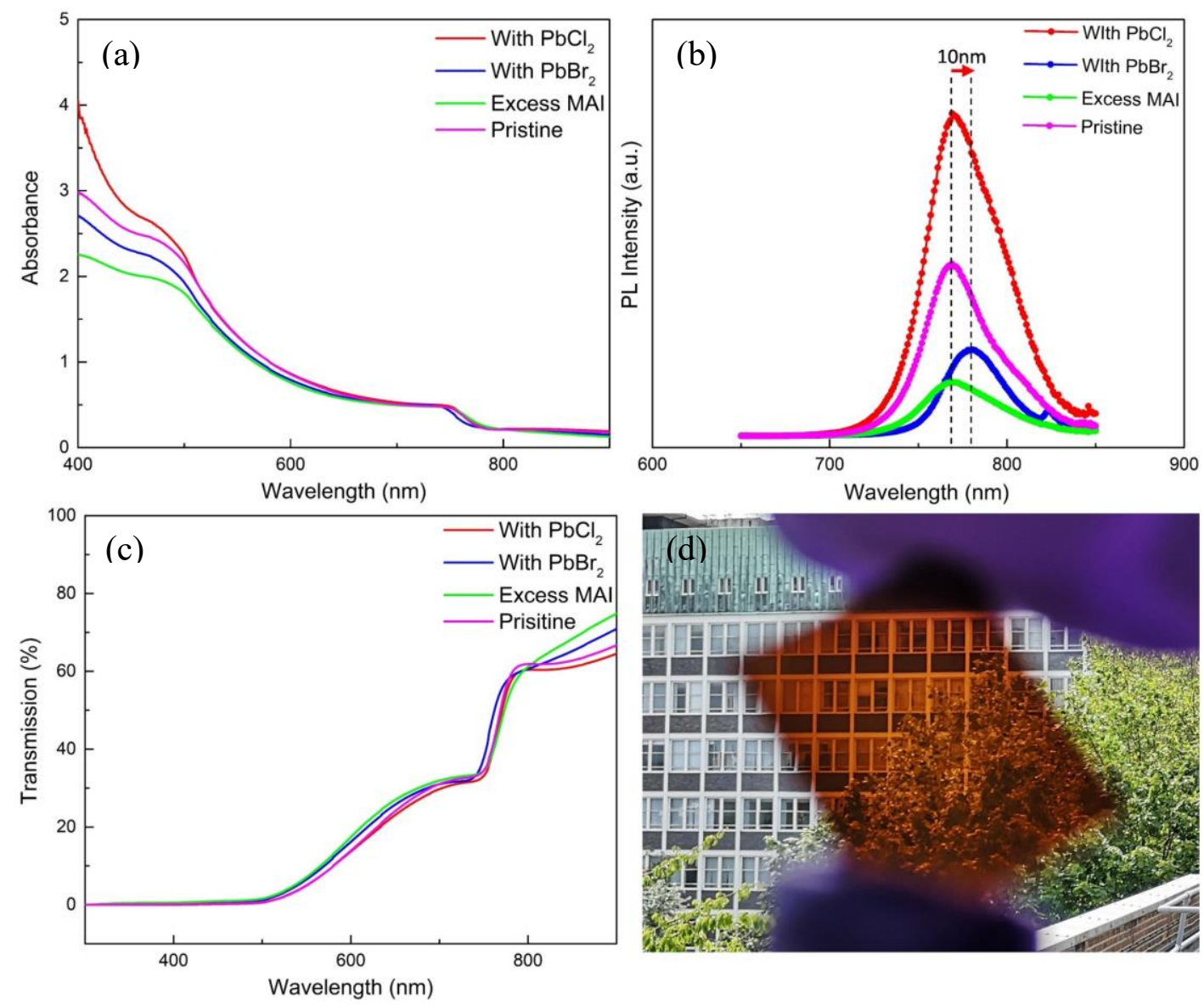

Fig. 7. Characterization of the pristine film and the films with excess $\mathrm{MAI}, \mathrm{PbCl}_{2}$ and $\mathrm{PbBr}_{2}$.

(a) absorbance measured by UV-Vis spectroscopy, (b) steady-state PL spectra. (C) transmission measured by UV-Vis spectroscopy. (d) an image of actual ambient-processed perovskite film with $\mathrm{PbCl}_{2}$.

The optical bandgaps of the different films are presented in Fig. S7, Both the pristine film and the film with $\mathrm{PbCl}_{2}$ additive have a bandgap of $1.58 \mathrm{eV}$. The film with excess MAI has a bandgap of $1.57 \mathrm{eV}$. The film with $\mathrm{PbBr}_{2}$ exhibits a slightly larger bandgap of $1.60 \mathrm{eV}$, in agreement with the observation of a lower $\mathbf{J}_{\mathrm{sc}}$ relative to the other PSCs [4]. However, the addition of $\mathrm{PbBr}_{2}$ shows no improvement in $\mathrm{Voc}$ for the devices in this study. This finding could be explained by a redshift $(10 \mathrm{~nm})$ from the PL peak, which possibly indicates the formation of deeper traps upon addition of $\mathrm{PbBr}_{2}$ [44]. The average visible transmissions (AVT) [45,46] calculated from the data in Fig. 7c between $370-740 \mathrm{~nm}$ are $11.48 \%, 13.04 \%, 11.06 \%$, and $12.30 \%$ for the pristine film and the films with the addition of excess $\mathrm{MAI}, \mathrm{PbCl}_{2}$ and $\mathrm{PbBr}_{2}$, 
respectively. Fig. 7d shows an image of the actual perovskite layer with addition $\mathrm{PbCl}_{2}$, with a thickness of around $230 \mathrm{~nm}$ measured from the cross-sectional SEM image shown in Fig. S8. The pristine film and the films with the addition of excess MAI and $\mathrm{PbBr}_{2}$ also shows a similar thickness, as shown in Fig. S8.

Having understood the improvement of photovoltaic performance by adding $\mathrm{PbCl}_{2}$ to the ambient-processed perovskite films, we further investigate their long-term stability by storing the devices without encapsulation in ambient air under RH of 50-60\%. Fig. 8a shows the PCEs as a function of aging time for the pristine devices and the devices with $\mathrm{PbCl}_{2}$ additive. The devices with $\mathrm{PbCl}_{2}$ additive retain $81 \%$ of their average initial PCEs of $15.42 \%$ and yield an average final PCEs of $12.50 \%$ after aging in ambient air for 28 days. The pristine devices show retention of $71 \%$ of their average initial PCEs of $13.70 \%$ and yield an average final PCEs of 9.74\%. We observe an increasing amount of degradation product $\mathrm{PbI}_{2}$ in the pristine film compared to the film with $\mathrm{PbCl}_{2}$ additive, evidenced by a stronger XRD peak intensity at $12.7^{\circ}$ in the pristine film compared to the film with $\mathrm{PbCl}_{2}$ additive (Fig. 8b) after aging in the ambient air for 14 days. The formation of more pinholes (red circles) also observed in the pristine films (Fig. 8c), compared to the film with added $\mathrm{PbCl}_{2}$ (Fig. 8d), after storage in air for 28 days further confirming better ambient stability for the film with the $\mathrm{PbCl}_{2}$ additive. Fig. S9 shows the digital images for the perovskite film with the addition of $\mathrm{PbCl}_{2}$ and the pristine film before and after storage in ambient air under RH of $50-60 \%$ for 30 days. It is noted that the perovskite film with the addition of $\mathrm{PbCl}_{2}$ shows less degradation than the pristine film. We find that better long-term stability of the devices with $\mathrm{PbCl}_{2}$ additive than the pristine film is mainly due to a smaller decrease of FF, as shown in Fig. S10 and S11. This result is possibly due to a higher uniformity and fewer pinholes of the perovskite film with the $\mathrm{PbCl}_{2}$ additive than the pristine one, which caused less nonradiative recombination and a more efficient charge transport at the interface [47]. Thermal stability for the device based on different additives has been studied by 
comparing their PCE before and after heating on a hotplate at $85^{\circ} \mathrm{C}$ for $1 \mathrm{~h}$, as shown in Fig. S12. It is noted that the devices based on the films with the addition of $\mathrm{PbBr}_{2}$ and $\mathrm{PbCl}_{2}$ showed less reduction on the PCE due to the thermal degradation than that of the films with excess MAI.
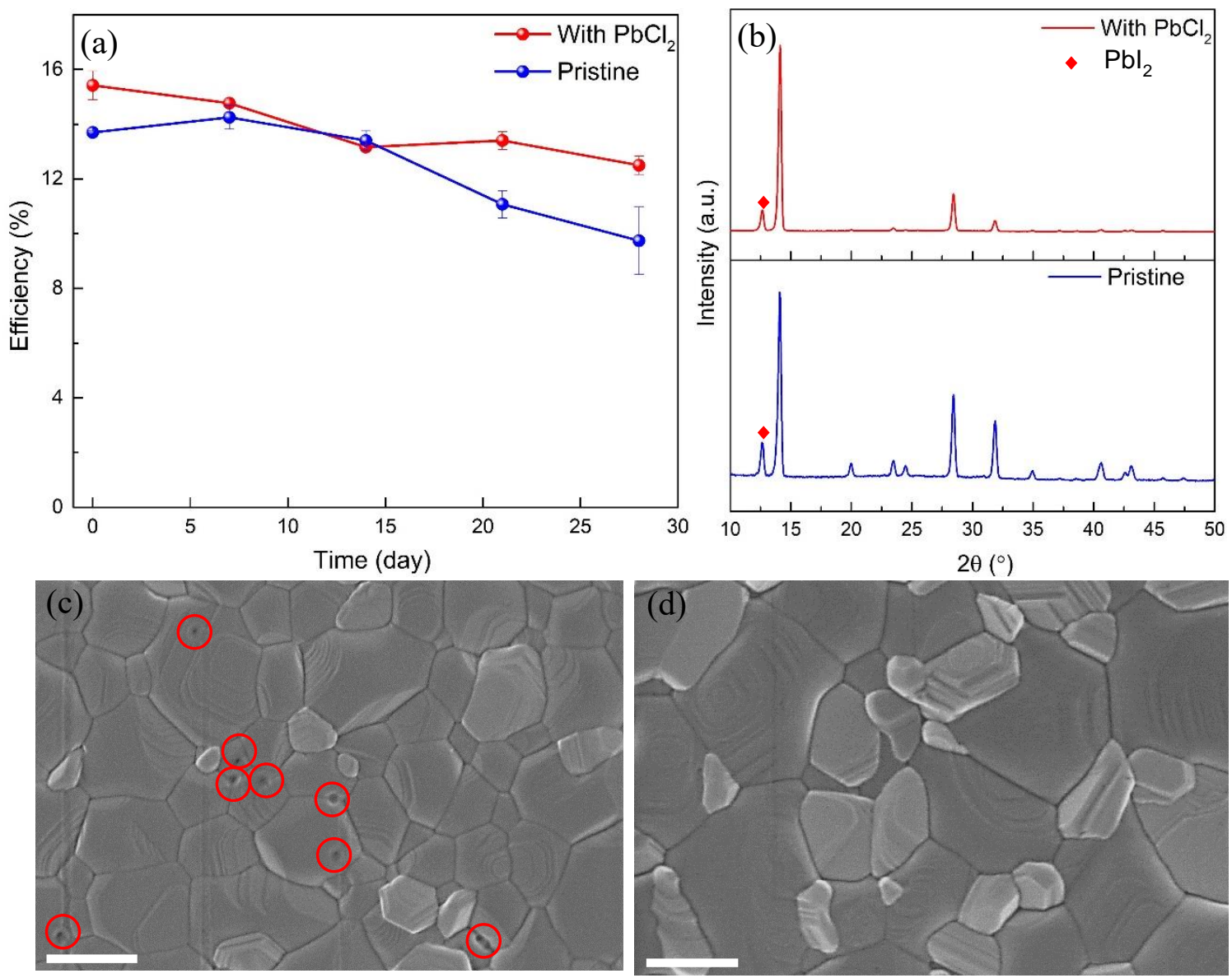

Fig. 8. (a) Long-term PCEs performance for the PSCs with pristine film and the film with addition of $\mathrm{PbCl}_{2}$ after storage in ambient air under $\mathrm{RH}$ of $50-60 \%$ for 28 days. (b) XRD pattern of pristine film and the film with addition of $\mathrm{PbCl}_{2}$ after storage in ambient air under RH of 50-60\% for 14 days. SEM (80 KX Magnification) images of perovskite film (c) pristine, (d) with $\mathrm{PbCl}_{2}$ addition after storage in ambient air with the relative humidity at 50$60 \%$ for 28 days. (scale bar $=400 \mathrm{~nm}$ )

\section{Conclusion}

In summary, we report the impact of adding $\mathrm{PbCl}_{2}, \mathrm{PbBr}_{2}$, and excess MAI in the perovskite precursors on the microstructure, chemical composition, crystallinity, optical properties, photovoltaic performance, and ambient stability with EA as antisolvent for ambient-processed 
perovskite films. Adding $\mathrm{PbCl}_{2}$ into the pristine perovskite films, leads to ambient-processed films with enlarged grain size with $\mathrm{PbI}_{2}$ located on the grain boundaries and surfaces, enhanced crystallinity, improved light absorption, and reduced nonradiative recombination. These effects induced by $\mathrm{PbCl}_{2}$ addition lead to a significant improvement in the device PCE up to $16.20 \%$ compared to a PCE of $13.81 \%$ for the pristine film. Device with $\mathrm{PbCl}_{2}$ addition also shows enhanced long-term stability performance with a retention of $81 \%$ of their initial PCE for the planar PSCs, after storage in ambient air for 28 days. The addition of $\mathrm{PbBr}_{2}$ reduces the hysteresis of the devices but gives no improvement in the PCE, possibly due to the formation of deeper trap states. The addition of excess MAI in this study shows negative effect on the device performance. Nevertheless, it is worth further investigating the effect of adding different ratios of the additives on the ambient-processed perovskite and PSCs. Our findings on the effect of halide additives for the fabrication of planar PSCs with green antisolvent in ambient air potentially contribute to the ambient and mass production of PSCs.

\section{Experimental Section}

Materials: Methylammonium Iodide (MAI, 98\%), spiro-MeOTAD (99.5\%), pre-patterned 8pixel ITO glass $(20 \Omega / \mathrm{sq})$ were purchased from Ossila. Lead iodide $\left(\mathrm{PbI}_{2}, 99.9985 \%\right)$ was purchased from Alfa Aesar. Lead chloride $\left(\mathrm{PbCl}_{2}, 99.999 \%\right)$, lead bromide $\left(\mathrm{PbBr}_{2}, 99.999 \%\right)$, ethyl acetate (99.8\%), dimethylformamide (DMF, 99.8\%), dimethyl sulfoxide (DMSO, 99.9\%), 4-tert-Butylpyridine (tBP, 98\%), acetonitrile (99.8\%), bis(trifluoromethane)sulfonimide lithium salt (99.95\%, LiTFSI), chlorobenzene (99.9\%), titanium diisopropoxide bis(acetylacetonate) (75 wt. \% in isopropanol), 1-Butanol (99.8\%) and Hellmanex III detergent were purchased from Sigma-Aldrich.

Perovskite precursor preparation: We prepared the pristine perovskite precursor by firstly dissolving $1.1 \mathrm{M} \mathrm{PbI}_{2}(506 \mathrm{mg}$ ) in a mixed solvent of $0.8 \mathrm{ml} \mathrm{DMF}$ and $0.15 \mathrm{ml} \mathrm{DMSO}$ and stirring at $70{ }^{\circ} \mathrm{C}$ for 20 mins. The $\mathrm{PbI}_{2}$ precursor solution was then cooled for 10 mins. 
Subsequently, 1.1 м MAI (175 mg) was added to the $\mathrm{PbI}_{2}$ precursor and stirred for 20 mins to complete the preparation. To prepare the perovskite precursor with $\mathrm{PbCl}_{2}, 1 \mathrm{M} \mathrm{PbI}_{2}$ (460 mg) and $0.1 \mathrm{M} \mathrm{PbCl}_{2}(28 \mathrm{mg})$ was added to the solvent and the same process described above for the preparation of pristine precursor, before adding the MAI, was followed. 1.2 м MAI (190 mg) was then added to the precursor and stirred for 20 mins to complete the preparation. To prepare the perovskite precursor with $\mathrm{PbBr}_{2}$, the $\mathrm{PbCl}_{2}(28 \mathrm{mg})$ was replaced by $0.1 \mathrm{M} \mathrm{PbBr}_{2}$ (37 $\mathrm{mg}$ ) and the rest of the process followed the preparation of the perovskite precursor with $\mathrm{PbCl}_{2}$. To prepare the perovskite precursor with excess MAI, an additional $0.1 \mathrm{M}$ MAI (16 mg) was added to the $\mathrm{PbI}_{2}$ solution and, the procedure for preparation of pristine perovskite precursor was followed as described above. The preparation of these precursors were based on the modification of the previous studies $[9,48,49]$.

Device fabrication: The pre-patterned ITO-coated glass was washed sequentially with $2 \%$ Hellmanex detergent in deionized water, ethanol, deionized water and then treated with UVozone for 15 mins. To prepare the compact $\mathrm{TiO}_{2}$ film, $0.1 \mathrm{M}$ titanium diisopropoxide bis(acetylacetonate) dissolved in 1-butanol was first spin-coated on the ITO-coated glass at $2000 \mathrm{rpm}$ for $40 \mathrm{~s}$ and then dried at $120{ }^{\circ} \mathrm{C}$ for $10 \mathrm{mins}$ in ambient air. $0.3 \mathrm{M}$ titanium diisopropoxide bis(acetylacetonate) in 1-butanol was then spin-coated under the same conditions. The substrates were finally annealed in the furnace at $500{ }^{\circ} \mathrm{C}$ for $30 \mathrm{mins}$ to complete the fabrication of compact $\mathrm{TiO}_{2}$. Before the deposition of the perovskite film, the substrates were exposed to UV-ozone for 15 mins and then preheated to $70{ }^{\circ} \mathrm{C}$ for 10 mins. The substrate was then quickly moved onto the spin-coater and $90 \mu \mathrm{l}$ of the perovskite precursor was spin-coated on the substrate at $4000 \mathrm{rpm}$ for 30 s. $200 \mu \mathrm{l}$ of ethyl acetate was added dropwise to the substrate at 6-8 s after starting the spin-coating process. The substrate was finally annealed at $120{ }^{\circ} \mathrm{C}$ for 10 mins to complete the formation of the perovskite film. To prepare the hole transport material spiro-MeOTAD, $43 \mathrm{mg}$ of spiro-OMeTAD was dissolved in $0.5 \mathrm{ml}$ of chlorobenzene and then mixed with $10 \mu \mathrm{l}$ of LiTFSI (520 mg in $1 \mathrm{ml}$ acetonitrile) and 
$15 \mu \mathrm{l}$ of tBP. The spiro-OMeTAD solution was then spin-coated on the perovskite film at 4000 rpm for $30 \mathrm{~s}$. Finally, $80 \mathrm{~nm}$ of gold was deposited onto the substrate by thermal evaporation to complete the device fabrication. Apart from the thermal evaporation, all processes were carried out in ambient conditions with RH of 50-60\%.

Characterizations: The $J-V$ curves were measured using an Ossila push-fit test board with a Keithley 2400 source meter under simulated AM 1.5 sunlight at $100 \mathrm{~mW} \mathrm{~cm}{ }^{-2}$ irradiated from an Oriel class AAA solar simulator. The light intensity was calibrated with a Newport calibrated quartz filtered Si reference cell. A measurement aperture mask with an aperture area of $2.4 \mathrm{~mm}^{2}$ was used to define the active area of the devices. The XRD pattern of the perovskite films was measured using a PANalytical XRD2 diffractometer. The morphology and cross-section of the perovskite films were investigated using a Zeiss Ultra 55 FEG-SEM with an inlens mode. PL spectra of the perovskite films were measured using an Edinburgh Instruments FLS980 spectrophotometer. The absorbance and transmission spectra were measured using a UV-vis spectrophotometer (Shimadzu UV-2401PC). The surface chemistry of the perovskite films was examined using a Kratos Axis Ultra X-ray Photoelectron Spectroscopy (XPS) equipped with a monochromated Al K $\alpha$ X-ray source with a photon energy of $1486.7 \mathrm{eV}$. All XPS data were analyzed using CasaXPS software.

\section{Supplementary data}

The supplementary data is available free of charge on the Publications website.

\section{Declaration of Competing Interest}

The authors declare no competing financial interests.

\section{Acknowledgments}

The authors would like to thank Dr. John Warren from the School of Materials, the University of Manchester, for his help on XRD characterization. The authors would like to thank Dr. Nam 
T. Nguyen from the School of Materials, the University of Manchester, for his help on PL

Spectroscopy.

\section{References}

[1] Y. Cheng, F. So, S.-W. Tsang, Progress in air-processed perovskite solar cells: from crystallization to photovoltaic performance, Mater. Horizons. 6 (2019) 1611-1624. doi:10.1039/C9MH00325H.

[2] M. Pazoki, T. Edvinsson, Metal replacement in perovskite solar cell materials: chemical bonding effects and optoelectronic properties, Sustain. Energy Fuels. 2 (2018) 14301445. doi:10.1039/C8SE00143J.

[3] C. Dokkhan, M.Z. Mokhtar, Q. Chen, B.R. Saunders, N.W. Hodson, B. Hamilton, Using microgels to control the morphology and optoelectronic properties of hybrid organicinorganic perovskite films, Phys. Chem. Chem. Phys. 20 (2018) 27959-27969. doi:10.1039/C8CP05148H.

[4] S. Tombe, G. Adam, H. Heilbrunner, D.H. Apaydin, C. Ulbricht, N.S. Sariciftci, C.J. Arendse, E. Iwuoha, M.C. Scharber, Optical and electronic properties of mixed halide (X = I, Cl, Br) methylammonium lead perovskite solar cells, J. Mater. Chem. C. 5 (2017) 1714-1723. doi:10.1039/C6TC04830G.

[5] T. Zhang, H. Chen, Y. Bai, S. Xiao, L. Zhu, C. Hu, Q. Xue, S. Yang, Understanding the relationship between ion migration and the anomalous hysteresis in high-efficiency perovskite solar cells: A fresh perspective from halide substitution, Nano Energy. 26 (2016) 620-630. doi:https://doi.org/10.1016/j.nanoen.2016.05.052.

[6] L. Fagiolari, F. Bella, Carbon-based materials for stable, cheaper and large-scale processable perovskite solar cells, Energy Environ. Sci. (2019). doi:10.1039/C9EE02115A.

[7] J. Chun-Ren Ke, A.S. Walton, D.J. Lewis, A. Tedstone, P. O'Brien, A.G. Thomas, W.R. Flavell, In situ investigation of degradation at organometal halide perovskite surfaces by $\mathrm{X}$-ray photoelectron spectroscopy at realistic water vapour pressure, Chem. Commun. 53 (2017) 5231-5234. doi:10.1039/C7CC01538K.

[8] M.F. Mohamad Noh, N.A. Arzaee, I.N. Nawas Mumthas, N.A. Mohamed, S.N.F. Mohd Nasir, J. Safaei, A.R. bin M. Yusoff, M.K. Nazeeruddin, M.A. Mat Teridi, Highhumidity processed perovskite solar cells, J. Mater. Chem. A. (2020). doi:10.1039/D0TA01178A.

[9] J. Troughton, K. Hooper, T.M. Watson, Humidity resistant fabrication of CH3NH3PbI3 perovskite solar cells and modules, Nano Energy. 39 (2017) 60-68. doi:10.1016/j.nanoen.2017.06.039.

[10] Y. Cheng, X. Xu, Y. Xie, H.-W. Li, J. Qing, C. Ma, C.-S. Lee, F. So, S.-W. Tsang, 18\% High-Efficiency Air-Processed Perovskite Solar Cells Made in a Humid Atmosphere of 70\% RH, Sol. RRL. (2017) 1700097. doi:10.1002/solr.201700097.

[11] T. Singh, T. Miyasaka, Stabilizing the Efficiency Beyond 20\% with a Mixed Cation Perovskite Solar Cell Fabricated in Ambient Air under Controlled Humidity, Adv. Energy Mater. 8 (2018) 1700677. doi:10.1002/aenm.201700677.

[12] G.E. Eperon, S.N. Habisreutinger, T. Leijtens, B.J. Bruijnaers, J.J. van Franeker, D.W. deQuilettes, S. Pathak, R.J. Sutton, G. Grancini, D.S. Ginger, R.A.J. Janssen, A. Petrozza, H.J. Snaith, The Importance of Moisture in Hybrid Lead Halide Perovskite Thin Film Fabrication, ACS Nano. 9 (2015) 9380-9393. doi:10.1021/acsnano.5b03626.

[13] J. You, Y. (Michael) Yang, Z. Hong, T.-B. Song, L. Meng, Y. Liu, C. Jiang, H. Zhou, W.-H. Chang, G. Li, Y. Yang, Moisture assisted perovskite film growth for high performance solar cells, Appl. Phys. Lett. 105 (2014) 183902. doi:10.1063/1.4901510. 
[14] D. Angmo, X. Peng, A. Seeber, C. Zuo, M. Gao, Q. Hou, J. Yuan, Q. Zhang, Y.-B. Cheng, D. Vak, Controlling Homogenous Spherulitic Crystallization for High-Efficiency Planar Perovskite Solar Cells Fabricated under Ambient High-Humidity Conditions, Small. 15 (2019) 1904422. doi:10.1002/smll.201904422.

[15] Z. Yang, C.C. Chueh, F. Zuo, J.H. Kim, P.W. Liang, A.K.Y. Jen, High-Performance Fully Printable Perovskite Solar Cells via Blade-Coating Technique under the Ambient Condition, Adv. Energy Mater. 5 (2015). doi:10.1002/aenm.201500328.

[16] M. Li, Y.-M. Xie, X. Xu, Y. Huo, S.-W. Tsang, Q.-D. Yang, Y. Cheng, Comparison of processing windows and electronic properties between $\mathrm{CH} 3 \mathrm{NH} 3 \mathrm{PbI} 3$ perovskite fabricated by one-step and two-step solution processes, Org. Electron. 63 (2018) 159165. doi:https://doi.org/10.1016/j.orgel.2018.09.011.

[17] J. Su, H. Cai, X. Ye, X. Zhou, J. Yang, D. Wang, J. Ni, J. Li, J. Zhang, Efficient Perovskite Solar Cells Prepared by Hot Air Blowing to Ultrasonic Spraying in Ambient Air, ACS Appl. Mater. Interfaces. 11 (2019) 10689-10696. doi:10.1021/acsami.9b01843.

[18] C. Liu, W. Ding, X. Zhou, J. Gao, C. Cheng, X. Zhao, B. Xu, Efficient and Stable Perovskite Solar Cells Prepared in Ambient Air Based on Surface-Modified Perovskite Layer, J. Phys. Chem. C. 121 (2017) 6546-6553. doi:10.1021/acs.jpcc.7b00847.

[19] Q. Tai, P. You, H. Sang, Z. Liu, C. Hu, H.L.W. Chan, F. Yan, Efficient and stable perovskite solar cells prepared in ambient air irrespective of the humidity, Nat. Commun. 7 (2016) 11105. doi:10.1038/ncomms11105.

[20] Y. Guo, L. Kang, M. Zhu, Y. Zhang, X. Li, P. Xu, A strategy toward air-stable and highperformance ZnO-based perovskite solar cells fabricated under ambient conditions, Chem. Eng. J. 336 (2018) 732-740. doi:https://doi.org/10.1016/j.cej.2017.11.189.

[21] G. Jang, H.-C. Kwon, S. Ma, S.-C. Yun, H. Yang, J. Moon, Cold Antisolvent Bathing Derived Highly Efficient Large-Area Perovskite Solar Cells, Adv. Energy Mater. 9 (2019) 1901719. doi:10.1002/aenm.201901719.

[22] L. Liang, Z. Li, F. Zhou, Q. Wang, H. Zhang, Z. Xu, L. Ding, S. (Frank) Liu, Z. Jin, The humidity-insensitive fabrication of efficient $\mathrm{CsPbI} 3$ solar cells in ambient air, J. Mater. Chem. A. 7 (2019) 26776-26784. doi:10.1039/C9TA10597B.

[23] D. Gedamu, I.M. Asuo, D. Benetti, M. Basti, I. Ka, S.G. Cloutier, F. Rosei, R. Nechache, Solvent-Antisolvent Ambient Processed Large Grain Size Perovskite Thin Films for High-Performance Solar Cells, Sci. Rep. 8 (2018) 12885. doi:10.1038/s41598-01831184-0.

[24] F. Yang, M.A. Kamarudin, P. Zhang, G. Kapil, T. Ma, S. Hayase, Enhanced Crystallization by Methanol Additive in Antisolvent for Achieving High-Quality MAPbI3 Perovskite Films in Humid Atmosphere, ChemSusChem. 11 (2018) 2348-2357. doi:10.1002/cssc.201800625.

[25] K. Sveinbjörnsson, K. Aitola, J. Zhang, M.B. Johansson, X. Zhang, J.-P. Correa-Baena, A. Hagfeldt, G. Boschloo, E.M.J. Johansson, Ambient air-processed mixed-ion perovskites for high-efficiency solar cells, J. Mater. Chem. A. 4 (2016) 16536-16545. doi:10.1039/C6TA06912F.

[26] M. Yavari, M. Mazloum-Ardakani, S. Gholipour, M.M. Tavakoli, S.-H. Turren-Cruz, N. Taghavinia, M. Grätzel, A. Hagfeldt, M. Saliba, Greener, Nonhalogenated Solvent Systems for Highly Efficient Perovskite Solar Cells, Adv. Energy Mater. 8 (2018) 1800177. doi:10.1002/aenm.201800177.

[27] J. Yi, J. Zhuang, Z. Ma, Z. Guo, W. Zhou, S. Zhao, H. Zhang, X. Luo, H. Li, Regulated perovskite crystallinity via green mixed antisolvent for efficient perovskite solar cells, Org. Electron. 69 (2019) 69-76. doi:https://doi.org/10.1016/j.orgel.2019.03.021.

[28] K.H. Young, S.L. Bullock, D.M. Melvin, C.L. Spruill, Ethyl acetate as a substitute for diethyl ether in the formalin-ether sedimentation technique, J. Clin. Microbiol. 10 (1979) 852-853. https://pubmed.ncbi.nlm.nih.gov/574877. 
[29] W. Li, W. Zhang, S. Van Reenen, R.J. Sutton, J. Fan, A.A. Haghighirad, M.B. Johnston, L. Wang, H.J. Snaith, Enhanced UV-light stability of planar heterojunction perovskite solar cells with caesium bromide interface modification, Energy Environ. Sci. 9 (2016) 490-498. doi:10.1039/C5EE03522H.

[30] M. Kim, G.-H. Kim, T.K. Lee, I.W. Choi, H.W. Choi, Y. Jo, Y.J. Yoon, J.W. Kim, J. Lee, D. Huh, H. Lee, S.K. Kwak, J.Y. Kim, D.S. Kim, Methylammonium Chloride Induces Intermediate Phase Stabilization for Efficient Perovskite Solar Cells, Joule. 3 (2019) 2179-2192. doi:https://doi.org/10.1016/j.joule.2019.06.014.

[31] H. Zhang, Y. Lv, J. Wang, H. Ma, Z. Sun, W. Huang, Influence of Cl Incorporation in Perovskite Precursor on the Crystal Growth and Storage Stability of Perovskite Solar Cells, ACS Appl. Mater. Interfaces. 11 (2019) 6022-6030. doi:10.1021/acsami.8b19390.

[32] H. Gao, C. Bao, F. Li, T. Yu, J. Yang, W. Zhu, X. Zhou, G. Fu, Z. Zou, Nucleation and Crystal Growth of Organic-Inorganic Lead Halide Perovskites under Different Relative Humidity, ACS Appl. Mater. Interfaces. 7 (2015) 9110-9117. doi:10.1021/acsami.5b00895.

[33] G. Wang, D. Liu, J. Xiang, D. Zhou, K. Alameh, B. Ding, Q. Song, Efficient perovskite solar cell fabricated in ambient air using one-step spin-coating, RSC Adv. 6 (2016) 43299-43303. doi:10.1039/C6RA05893K.

[34] Q. Chen, H. Zhou, T. Bin Song, S. Luo, Z. Hong, H.S. Duan, L. Dou, Y. Liu, Y. Yang, Controllable self-induced passivation of hybrid lead iodide perovskites toward high performance solar cells, Nano Lett. 14 (2014) 4158-4163. doi:10.1021/nl501838y.

[35] A. Binek, I. Grill, N. Huber, K. Peters, A.G. Hufnagel, M. Handloser, P. Docampo, A. Hartschuh, T. Bein, Control of Perovskite Crystal Growth by Methylammonium Lead Chloride Templating, Chem. - An Asian J. 11 (2016) 1199-1204. doi:10.1002/asia.201501379.

[36] M.Z. Mokhtar, Q. Chen, Q. Lian, D.J. Lewis, B.R. Saunders, A.S. Walton, C.-R. Ke, E. Whittaker, B. Hamilton, S. Haque, Decoupling Structure and Composition of $\mathrm{CH}_{3} \mathrm{NH}$ ${ }_{3} \mathrm{PbI}{ }_{3-x} \mathrm{Br}_{x}$ Films Prepared by Combined One-Step and Two-Step Deposition, ACS Appl. Energy Mater. 1 (2018) 5567-5578. doi:10.1021/acsaem.8b01128.

[37] C.-R. Ke, D.J. Lewis, A.S. Walton, Q. Chen, B.F. Spencer, M.Z. Mokhtar, C.L. Compean-Gonzalez, P. O'Brien, A.G. Thomas, W.R. Flavell, Air-Stable Methylammonium Lead Iodide Perovskite Thin Films Fabricated via Aerosol-Assisted Chemical Vapor Deposition from a Pseudohalide $\mathrm{Pb}(\mathrm{SCN})_{2}$ Precursor, ACS Appl. Energy Mater. 2 (2019) 6012-6022. doi:10.1021/acsaem.9b01124.

[38] B. Philippe, B.-W. Park, R. Lindblad, J. Oscarsson, S. Ahmadi, E.M.J. Johansson, H. Rensmo, Chemical and Electronic Structure Characterization of Lead Halide Perovskites and Stability Behavior under Different Exposures-A Photoelectron Spectroscopy Investigation, Chem. Mater. 27 (2015) 1720-1731. doi:10.1021/acs.chemmater.5b00348.

[39] J. Yang, A. Xiao, L. Xie, K. Liao, X. Deng, C. Li, A. Wang, Y. Xiang, T. Li, F. Hao, Precise control of $\mathrm{PbI} 2$ excess into grain boundary for efficacious charge extraction in off-stoichiometric perovskite solar cells, Electrochim. Acta. 338 (2020) 135697. doi:https://doi.org/10.1016/j.electacta.2020.135697.

[40] P. Liu, W. Wang, S. Liu, H. Yang, Z. Shao, Fundamental Understanding of Photocurrent Hysteresis in Perovskite Solar Cells, Adv. Energy Mater. 9 (2019) 1803017. doi:10.1002/aenm.201803017.

[41] Q. Wei, Z. Yang, D. Yang, F. Fu, S. (Frank) Liu, Abnormal absorption onset shift of $\mathrm{CH} 3 \mathrm{NH} 3 \mathrm{PbI} 3$ film by adding $\mathrm{PbBr} 2$ into its precursor and its effect on photovoltaic performance, J. Power Sources. 437 (2019) 226914. doi: 10.1016/j.jpowsour.2019.226914.

[42] D.-Y. Son, J.-W. Lee, Y.J. Choi, I.-H. Jang, S. Lee, P.J. Yoo, H. Shin, N. Ahn, M. Choi, D. Kim, N.-G. Park, Self-formed grain boundary healing layer for highly efficient 
CH3NH3PbI3 perovskite solar cells, Nat. Energy. 1 (2016) 16081. doi:10.1038/nenergy.2016.81.

[43] K. Liao, J. Yang, C. Li, T. Li, F. Hao, Off-Stoichiometric Methylammonium Iodide Passivated Large-Grain Perovskite Film in Ambient Air for Efficient Inverted Solar Cells, ACS Appl. Mater. Interfaces. 11 (2019) 39882-39889. doi:10.1021/acsami.9b12829.

[44] K. Lu, C. Zhao, L. Luan, J. Duan, Y. Xie, M. Shao, B. Hu, Exploring the role of spintriplets and trap states in photovoltaic processes of perovskite solar cells, J. Mater. Chem. C. 6 (2018) 5055-5062. doi:10.1039/C8TC00455B.

[45] L. Yuan, Z. Wang, R. Duan, P. Huang, K. Zhang, Q. Chen, N.K. Allam, Y. Zhou, B. Song, Y. Li, Semi-transparent perovskite solar cells: unveiling the trade-off between transparency and efficiency, J. Mater. Chem. A. 6 (2018) 19696-19702. doi:10.1039/C8TA07318J.

[46] C. Dokkhan, M.Z. Mokhtar, C.-R. Ke, A.S. Walton, Q. Chen, N.W. Hodson, Q. Lian, B.R. Saunders, Modulating Crystallization in Semitransparent Perovskite Films Using Submicrometer Spongelike Polymer Colloid Particles to Improve Solar Cell Performance, ACS Appl. Energy Mater. 2 (2019) 6624-6633. doi:10.1021/acsaem.9b01162.

[47] T.-Y. Yang, N.J. Jeon, H.-W. Shin, S.S. Shin, Y.Y. Kim, J. Seo, Achieving Long-Term Operational Stability of Perovskite Solar Cells with a Stabilized Efficiency Exceeding $20 \%$ after 1000 h, Adv. Sci. 6 (2019) 1900528. doi:10.1002/advs.201900528.

[48] Q. Chen, M.Z. Mokhtar, J.C.-R. Ke, A.G. Thomas, A. Hadi, E. Whittaker, M. Curioni, Z. Liu, A one-step laser process for rapid manufacture of mesoscopic perovskite solar cells prepared under high relative humidity, Sustain. Energy Fuels. 2 (2018) 1216-1224. doi:10.1039/C8SE00043C.

[49] D. Liu, C.J. Traverse, P. Chen, M. Elinski, C. Yang, L. Wang, M. Young, R.R. Lunt, Aqueous-Containing Precursor Solutions for Efficient Perovskite Solar Cells, Adv. Sci. 5 (2018) 1700484. doi:10.1002/advs.201700484. 


\section{Supporting Information}

\section{Impact of Halide Additives on Green Antisolvent and High-Humidity Processed Perovskite Solar Cells}

Qian Chen ${ }^{a,{ }^{*}}$, Jack Chun-Ren Ke ${ }^{a, b}$, Dong Wang ${ }^{a}$, Muhamad Z. Mokhtar ${ }^{a}$, Andrew G. Thomas $^{a, b}$, Zhu Liu ${ }^{a, *}$

${ }^{\text {a }}$ Department of Materials, The University of Manchester, Oxford Road, Manchester, M13 9PL, UK

${ }^{\mathrm{b}}$ Photon Science Institute, The University of Manchester, Oxford Road, Manchester, M13 9PL, UK

* Corresponding author.

E-mail address: qian.chen-2@manchester.ac.uk, zhu.liu@manchester.ac.uk
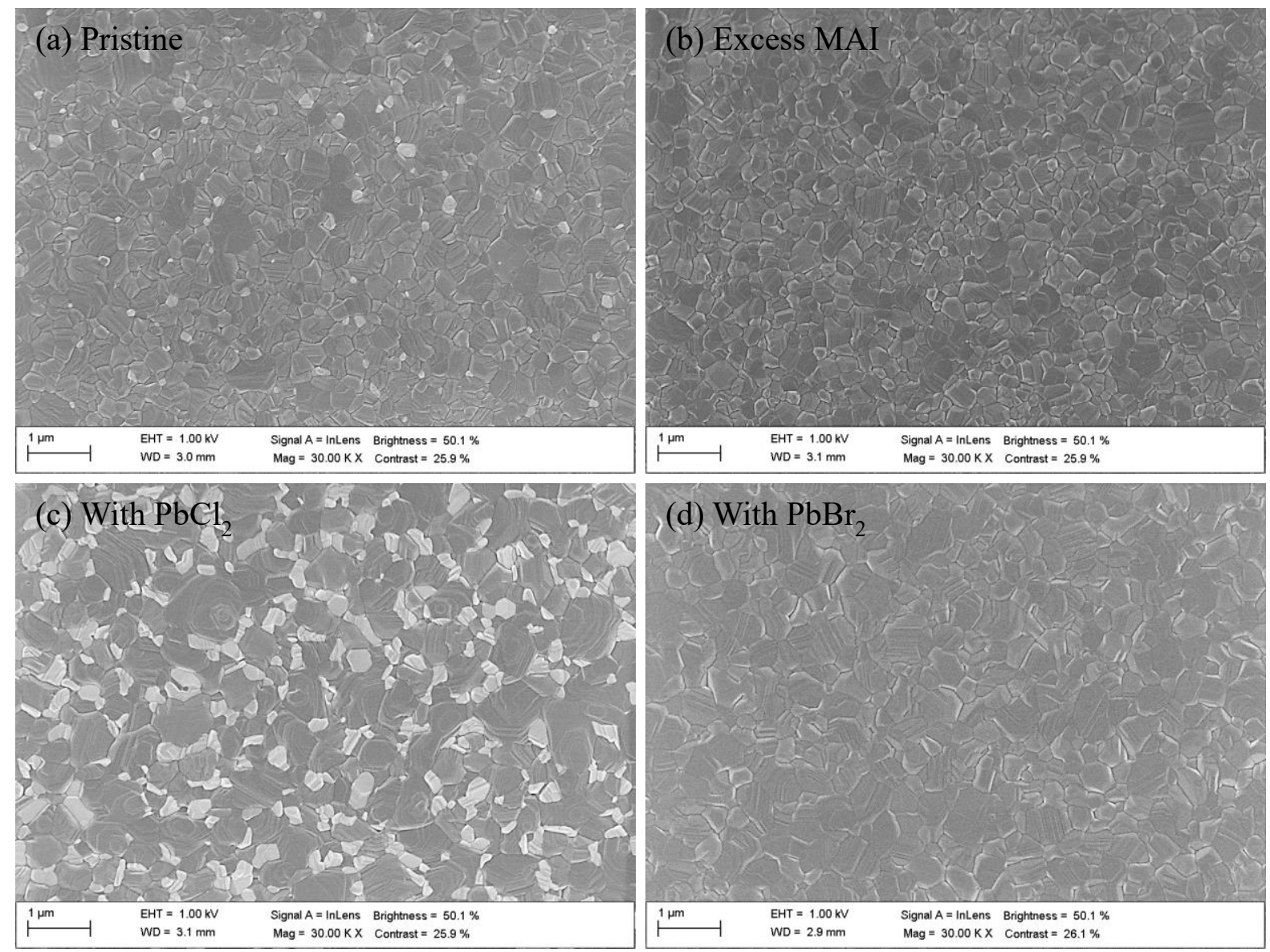

Fig. S1 SEM (30 KX magnification) images for the perovskite films (a) pristine, (b) excess MAI, (c) with $\mathrm{PbCl}_{2}$ and (d) with $\mathrm{PbBr}_{2}$. 

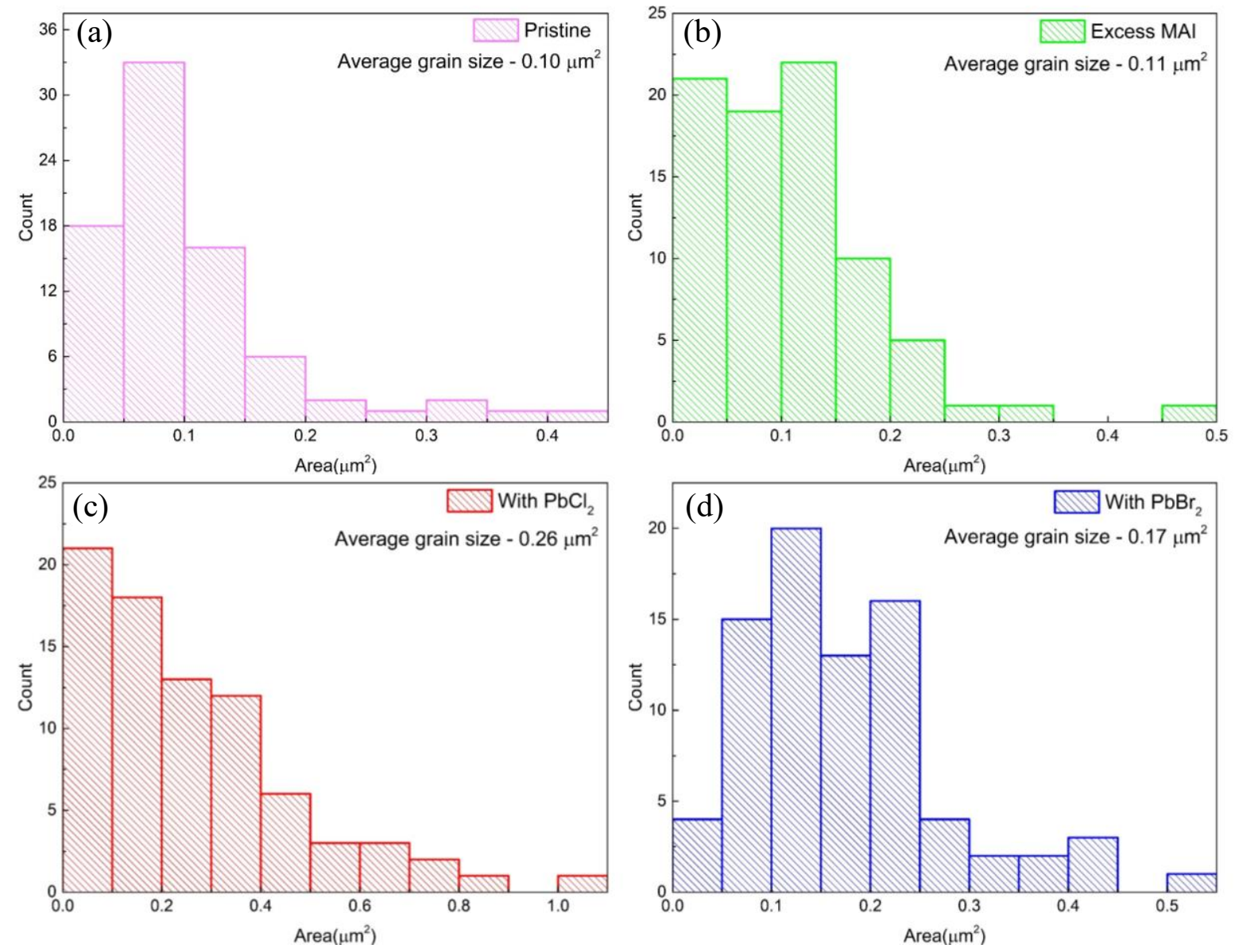

Fig. S2 Grain size distribution for the perovskite films (a) pristine, (b) excess MAI, (c) with $\mathrm{PbCl}_{2}$ and (d) with $\mathrm{PbBr}_{2}$. 


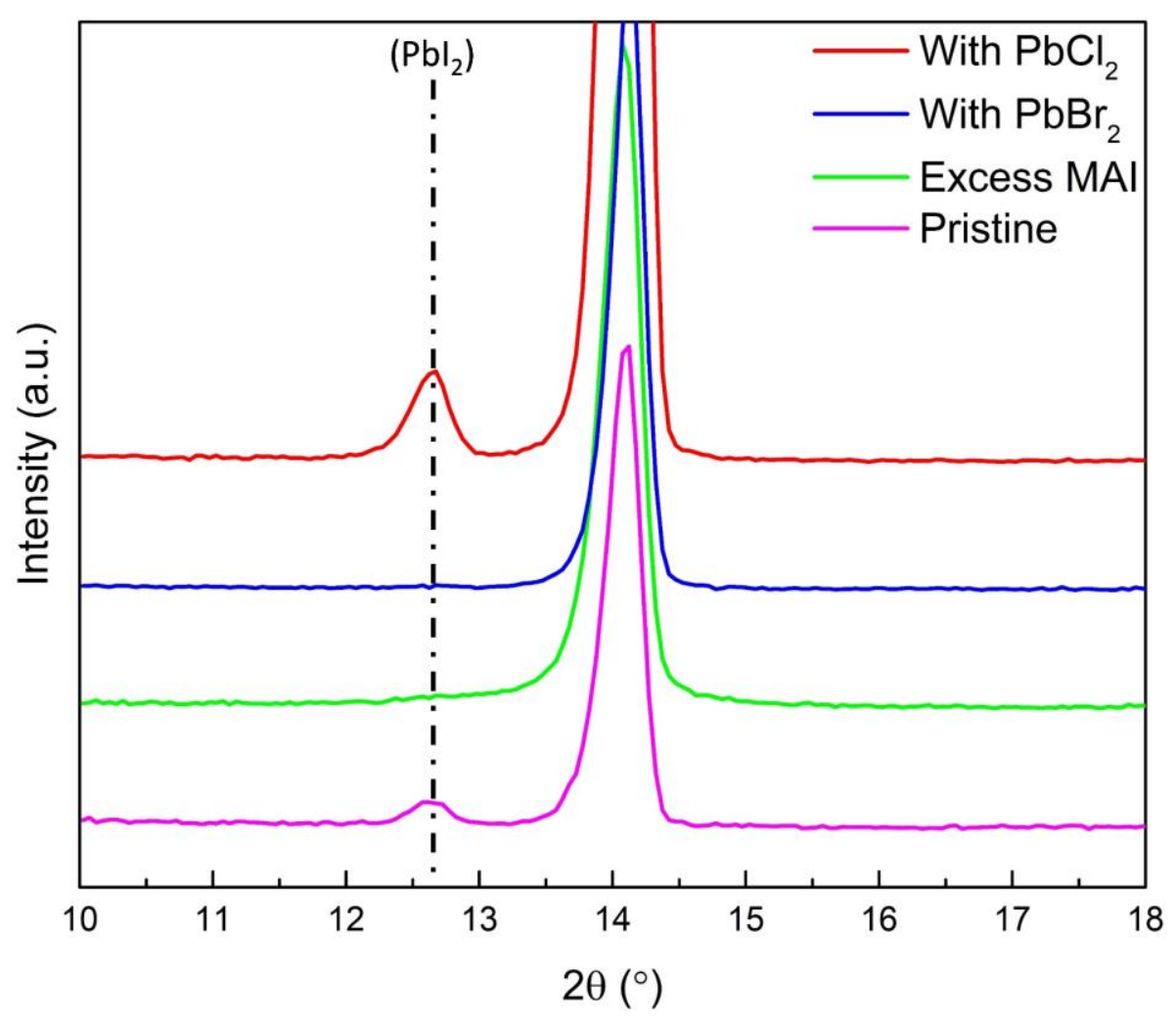

Fig. S3 XRD pattern for pristine perovskite film and the films with the addition of $\mathrm{PbCl}_{2}$, $\mathrm{PbBr}_{2}$, and excess MAI at the $2 \theta$ range of $10-18^{\circ}$.

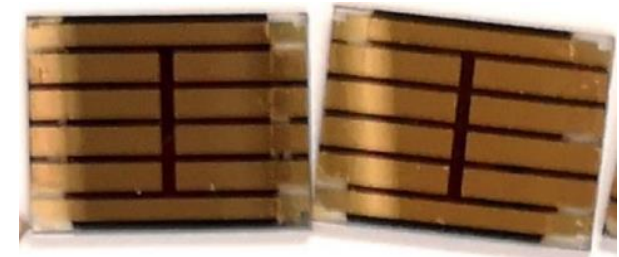

Fig. S4 An image of actual ambient-processed planar PSCs with an architecture of ITOglass/TiO $/$ /perovskite/spiro-OMeTAD/Au. 

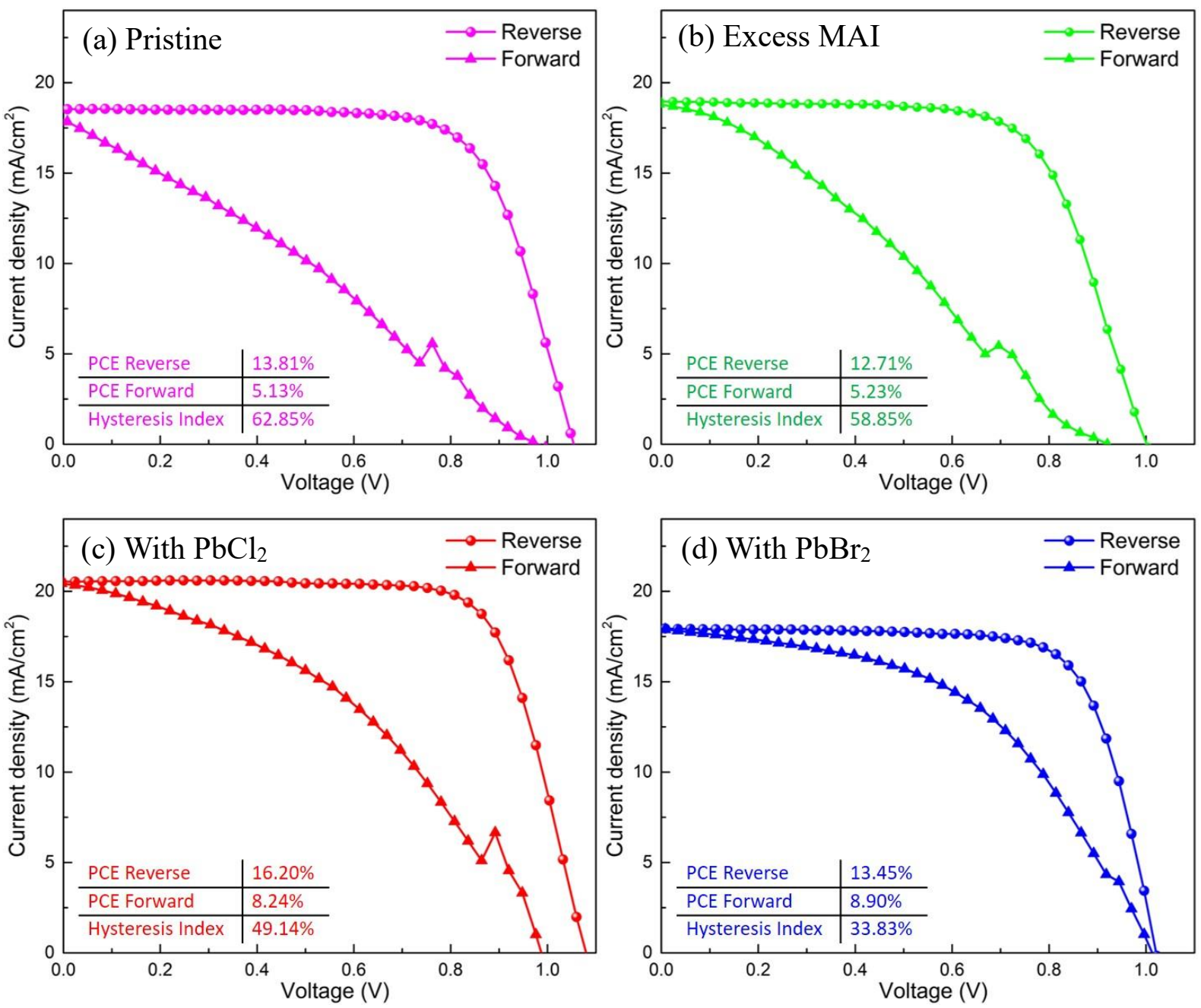

Fig. S5 Current density-voltage $(J-V)$ curves for the devices with (a) pristine film, (b) the films with the addition of excess MAI, (c) $\mathrm{PbCl}_{2}$ and (d) $\mathrm{PbBr}_{2}$ measured from reverse scan (RS) and forward scan (FS) under simulated AM1.5 sunlight measured in ambient air. 


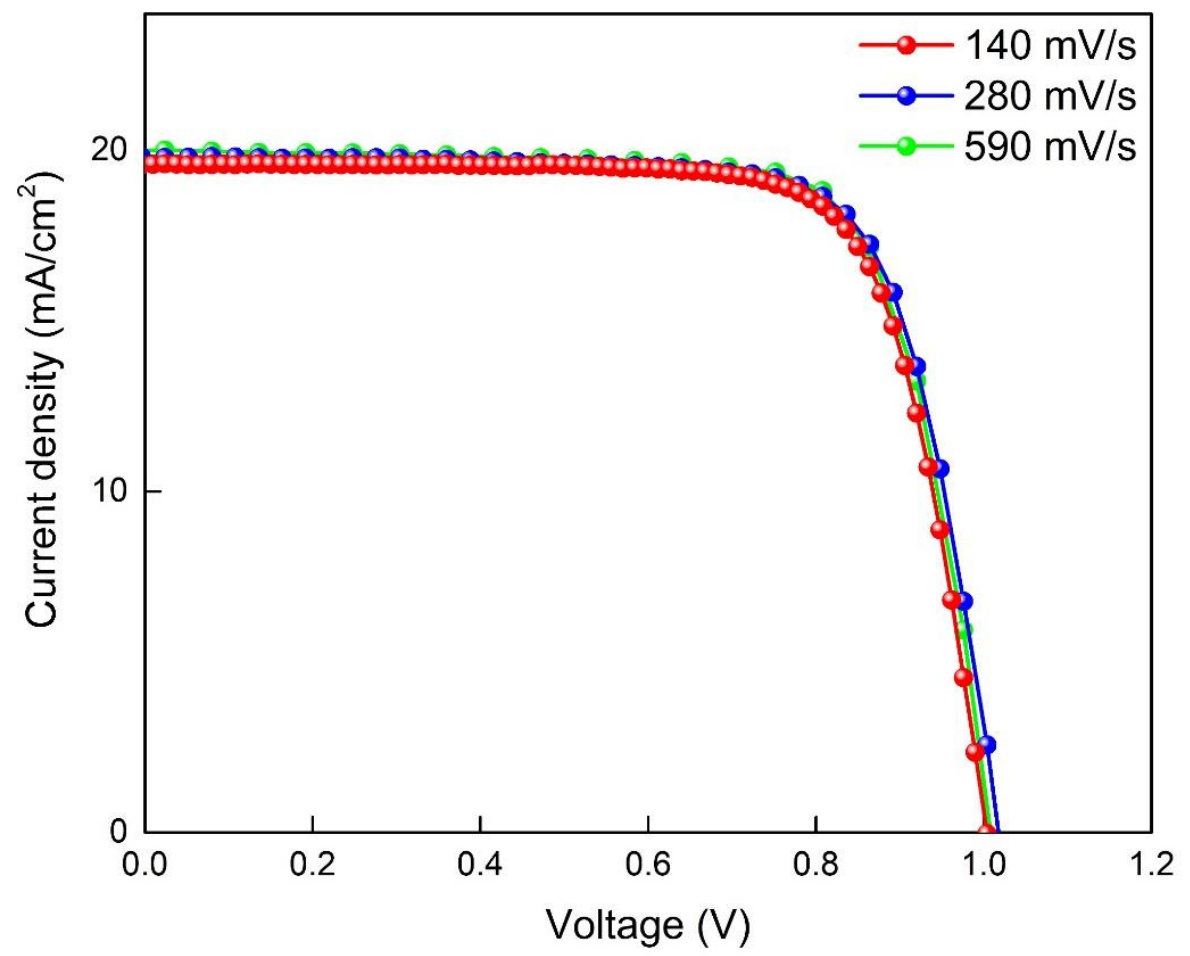

Fig. S6 Current density-voltage $(J-V)$ curves of the devices with the addition of $\mathrm{PbCl}_{2}$ measured from reverse scan under different scanning rate. 

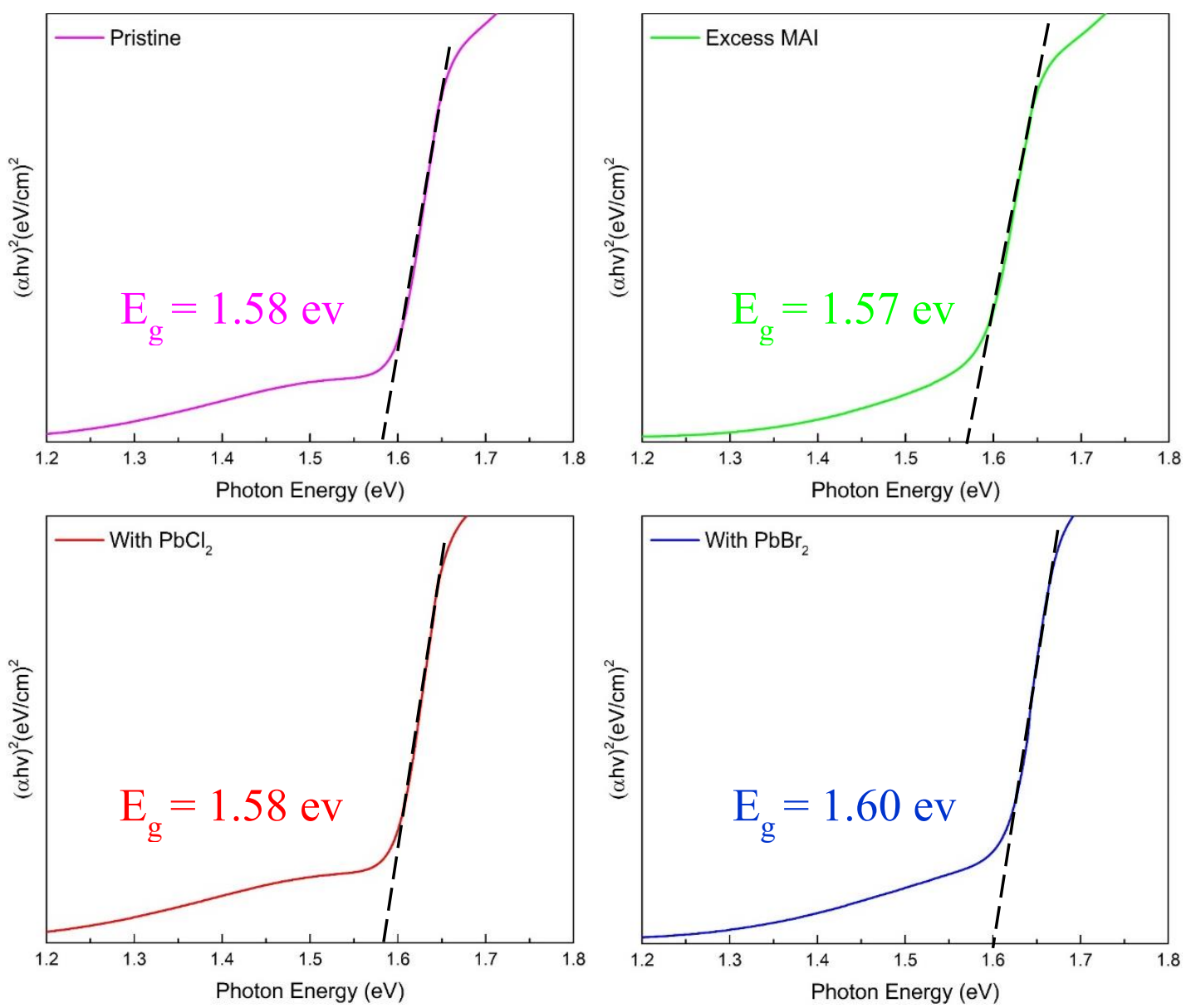

Fig. S7 Optical bandgaps calculated from Uv-vis spectra for pristine perovskite film and the films with the addition of $\mathrm{PbCl}_{2}, \mathrm{PbBr}_{2}$, and excess MAI. 

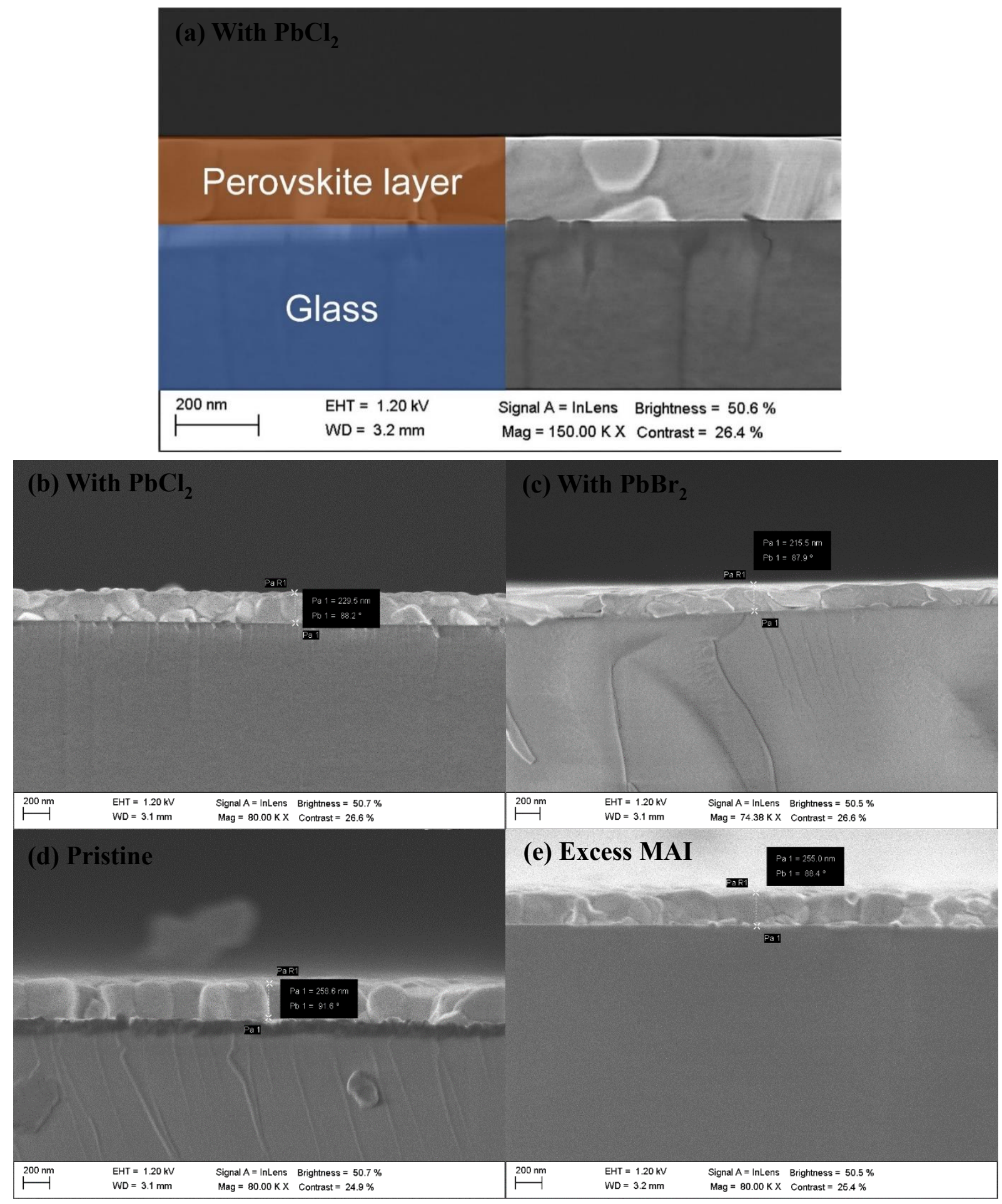

Fig. S8 SEM cross-section image of perovskite films (a) and (b) with $\mathrm{PbCl}_{2}$, (c) with $\mathrm{PbBr}_{2}$, (d) pristine and (e) excess MAI. 


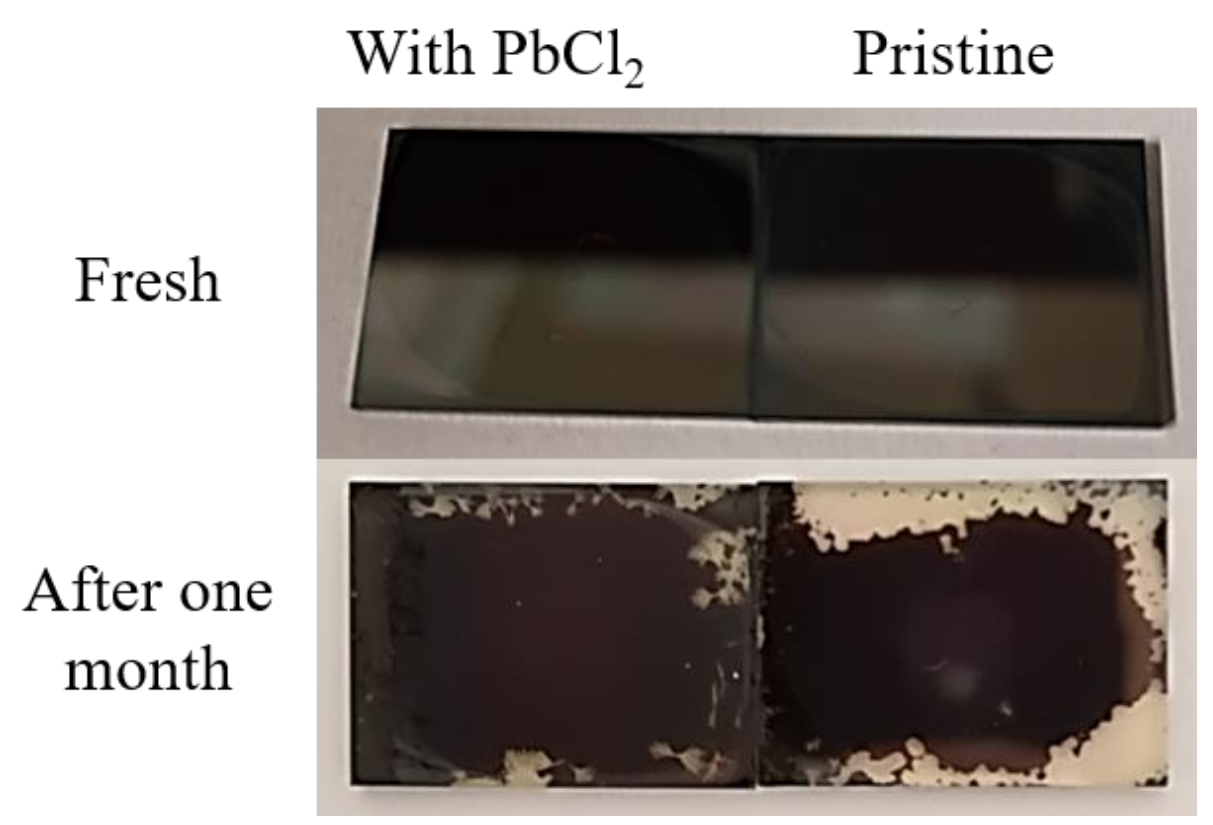

Fig.S9 Digital images of perovskite film with the addition of $\mathrm{PbCl}_{2}$ and the pristine film before and after storage in ambient air under RH of 50-60\% for 30 days.
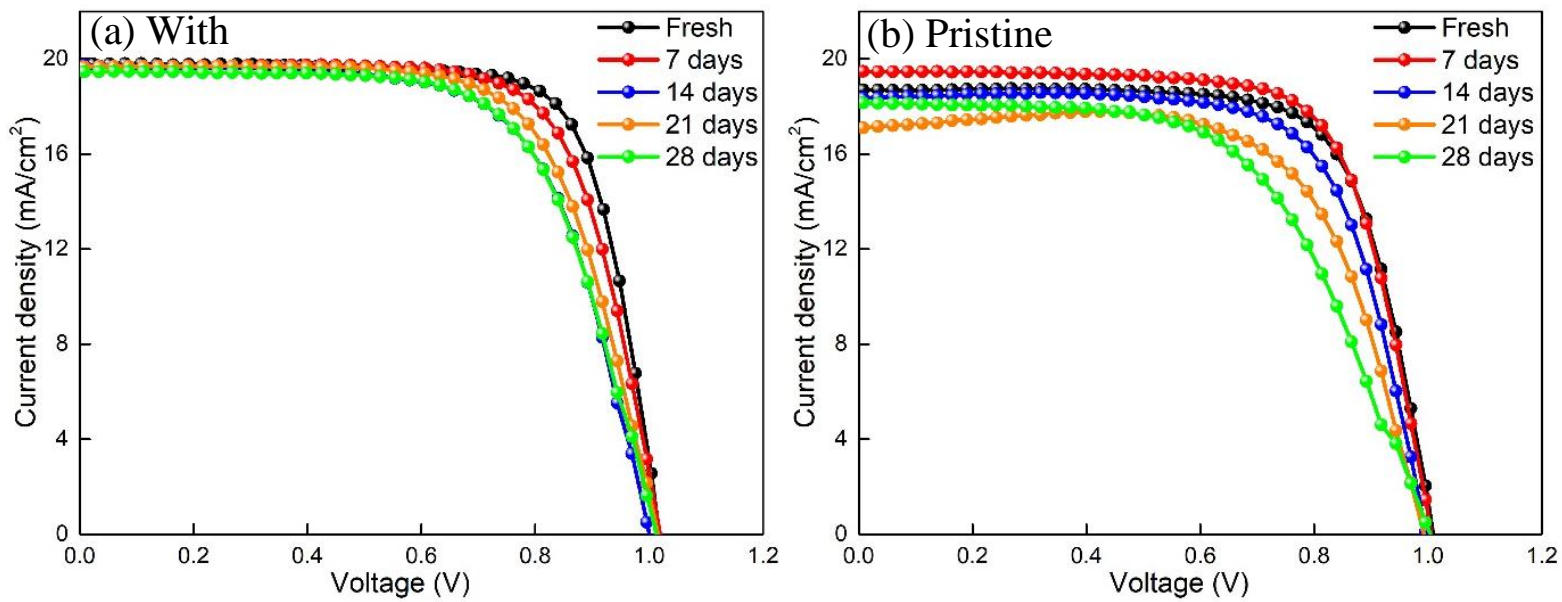

Fig.S10 $J$ - $V$ curves for the devices based on (a) the perovskite film with the addition of $\mathrm{PbCl}_{2}$ and (b) the pristine perovskite film after storage in ambient air under $\mathrm{RH}$ of $50-60 \%$ at $0,7,14,21$ and 28 days. 

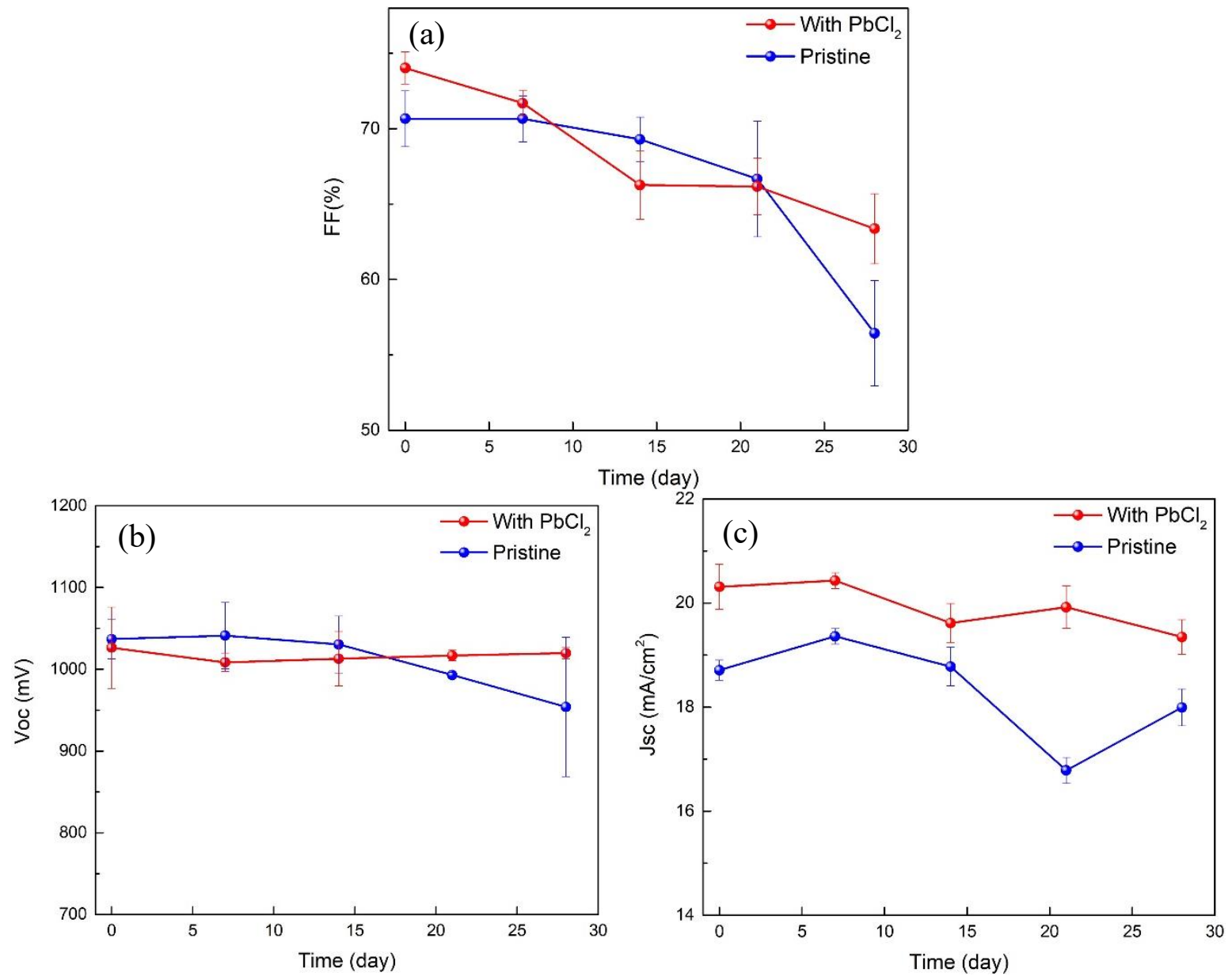

Fig. S11 Change of (a) FF, (b) $V_{o c}$ and (c) $J_{s c}$ versus storage time for the devices based on the pristine perovskite film and the film with the addition of $\mathrm{PbCl}_{2}$. 

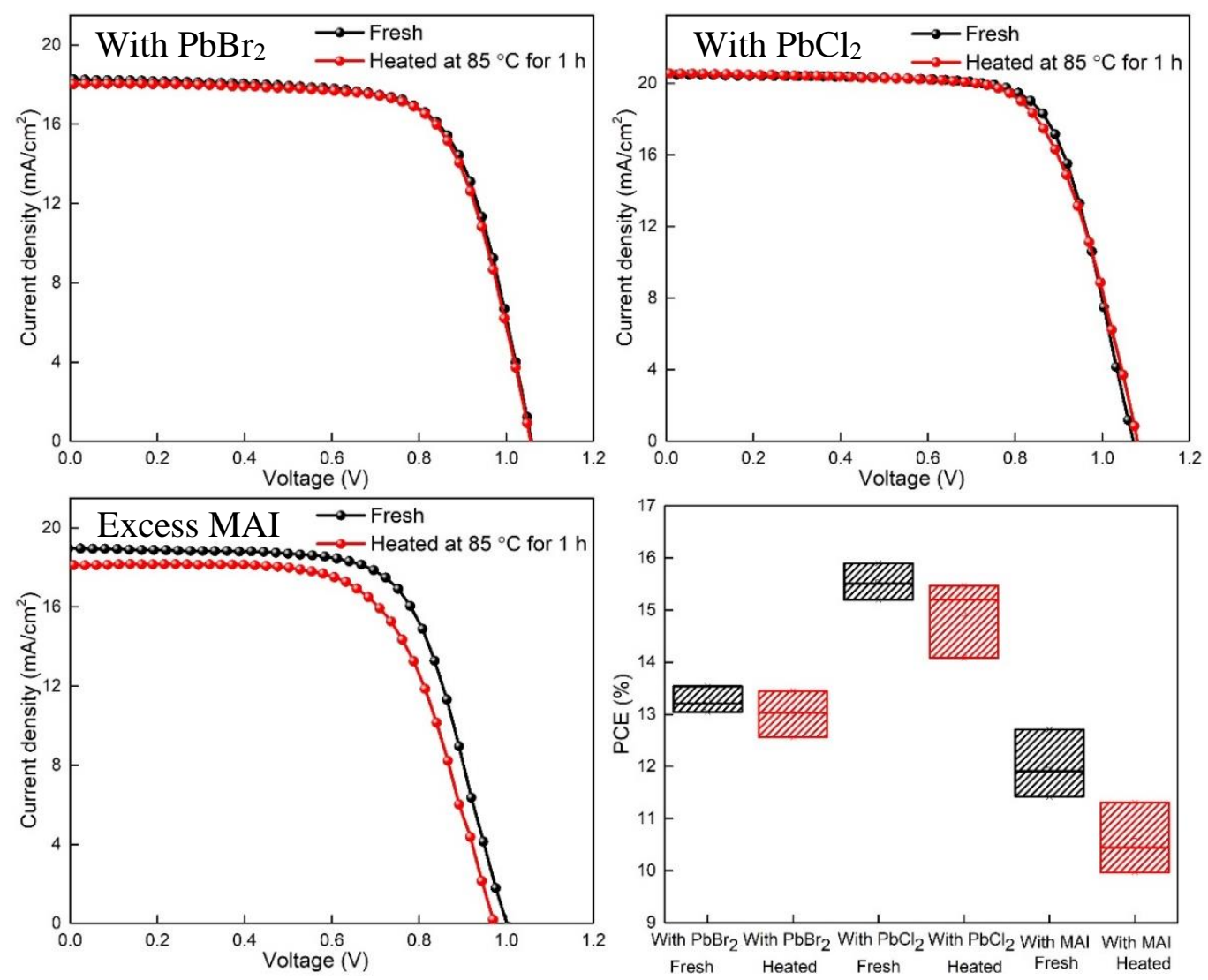

Fig. S12 J-V curves for the devices based on the perovskite films with the addition of (a) $\mathrm{PbBr}_{2}$, (b) $\mathrm{PbCl}_{2}$ and (c) excess MAI before and after heating on a hotplate at $85^{\circ} \mathrm{C}$ for $1 \mathrm{~h}$. (d) PCE distribution for the devices based on the films with different additives before and after heating on a hotplate at $85^{\circ} \mathrm{C}$ for $1 \mathrm{~h}$. 
Table S1. Crystal size for the pristine perovskite film and the films with different additives calculated by Scherrer equation

\begin{tabular}{|c|c|c|c|c|}
\hline $\begin{array}{c}\text { Types of } \\
\text { Perovskite }\end{array}$ & $\begin{array}{c}\text { Peak position } \\
2 \theta\left({ }^{\circ}\right)\end{array}$ & $\begin{array}{c}\text { FWHM } \\
\quad\left({ }^{0}\right)\end{array}$ & Peak intensity & $\begin{array}{c}\text { Crystal size } \\
\text { (nm) }\end{array}$ \\
\hline Pristine & 14.10 & 0.318 & 12125 & 25.16 \\
\hline Excess MAI & 14.07 & 0.354 & 16461 & 22.60 \\
\hline With $\mathrm{PbCl}_{2}$ & 14.12 & 0.286 & 50005 & 27.98 \\
\hline With PbBr2 & 14.12 & 0.291 & 15637 & 27.50 \\
\hline
\end{tabular}

Table S2 Elemental surface stoichiometries determined from XPS measurements for the pristine perovskite film and the films with the addition of excess $\mathrm{MAI}, \mathrm{PbCl}_{2}, \mathrm{PbBr}_{2}$

\begin{tabular}{|c|c|c|c|}
\hline Sample ID & I/Pb & $\mathbf{N} / \mathbf{P b}$ & $\mathbf{P b}^{\mathbf{0}} / \mathbf{P b}^{2+}$ \\
\hline Pristine & $2.6 \pm 0.1$ & $0.6 \pm 0.1$ & $22 \pm 2 \%$ \\
\hline Excess MAI & $2.9 \pm 0.1$ & $0.9 \pm 0.1$ & $6 \pm 2 \%$ \\
\hline With PbCl 2 & $2.7 \pm 0.1$ & $0.7 \pm 0.1$ & $16 \pm 2 \%$ \\
\hline With PbBr2 & $2.8 \pm 0.1$ & $0.8 \pm 0.1$ & $6 \pm 2 \%$ \\
\hline
\end{tabular}

Table S3 A summary of photovoltaic parameters for planar PSCs with the pristine perovskite film and the films with addition of excess MAI, $\mathrm{PbCl}_{2}, \mathrm{PbBr}_{2}$, under $\mathrm{RH}$ of $50-60 \%$.

\begin{tabular}{|c|c|c|c|c|c|}
\hline $\begin{array}{c}\text { Types of } \\
\text { Perovskite }\end{array}$ & $\begin{array}{l}\text { PCE } \\
(\%)\end{array}$ & $\begin{array}{l}\text { FF } \\
(\%)\end{array}$ & $\begin{array}{c}\mathrm{J}_{\mathrm{sc}} \\
\left(\mathrm{mA} / \mathrm{cm}^{2}\right)\end{array}$ & $\begin{array}{l}\mathbf{V}_{o c} \\
(\mathbf{m V})\end{array}$ & $\begin{array}{l}\text { HI } \\
(\%)\end{array}$ \\
\hline $\begin{array}{l}\text { With } \mathrm{PbCl}_{2} \\
\text { (best) }\end{array}$ & $\begin{array}{c}15.21 \pm 0.59 \\
(\mathbf{1 6 . 2 0})\end{array}$ & $\begin{array}{c}73.9 \pm 1.6 \\
(\mathbf{7 6 . 3})\end{array}$ & $\begin{array}{c}20.08 \pm 0.40 \\
(\mathbf{2 0 . 5 9})\end{array}$ & $\begin{array}{c}1025.2 \pm 34.8 \\
(\mathbf{1 0 7 9 . 9})\end{array}$ & 49.14 \\
\hline $\begin{array}{l}\text { With PbBr2 } \\
\text { (best) }\end{array}$ & $\begin{array}{c}12.82 \pm 0.46 \\
(\mathbf{1 3 . 5 4})\end{array}$ & $\begin{array}{c}70.7 \pm 2.0 \\
(\mathbf{7 3 . 4})\end{array}$ & $\begin{array}{c}17.94 \pm 0.32 \\
(\mathbf{1 8 . 3 3})\end{array}$ & $\begin{array}{c}1010.9 \pm 21.2 \\
(\mathbf{1 0 5 7 . 7})\end{array}$ & 33.83 \\
\hline $\begin{array}{l}\text { Excess MAI } \\
\text { (best) }\end{array}$ & $\begin{array}{c}12.40 \pm 0.53 \\
(\mathbf{1 3 . 4 8})\end{array}$ & $\begin{array}{c}67.8 \pm 2.3 \\
(\mathbf{7 0 . 4})\end{array}$ & $\begin{array}{c}18.45 \pm 0.56 \\
(\mathbf{1 9 . 0 8})\end{array}$ & $\begin{array}{c}992.4 \pm 23.7 \\
(\mathbf{1 0 5 8 . 8})\end{array}$ & 58.85 \\
\hline $\begin{array}{c}\text { Pristine } \\
\text { (best) }\end{array}$ & $\begin{array}{c}13.53 \pm 0.19 \\
(\mathbf{1 3 . 8 1})\end{array}$ & $\begin{array}{c}71.7 \pm 1.5 \\
(\mathbf{7 2 . 9})\end{array}$ & $\begin{array}{c}18.53 \pm 0.28 \\
(\mathbf{1 8 . 9 1})\end{array}$ & $\begin{array}{c}1019.5 \pm 21.4 \\
(\mathbf{1 0 5 4 . 5})\end{array}$ & 62.85 \\
\hline
\end{tabular}


Table S4 A summary of PCEs for recent ambient-processed PSCs in comparison to our planar PSCs

\begin{tabular}{|c|c|c|c|c|}
\hline Perovskite type & $\begin{array}{c}\text { Average PCE } \\
\text { (best PCE) }\end{array}$ & $\begin{array}{c}\text { Deposition } \\
\text { method }\end{array}$ & Humidity & Reference \\
\hline $\mathrm{CH}_{3} \mathrm{NH}_{3} \mathrm{PbI}_{3}$ with $\mathrm{PbCl}_{2}$ & $\begin{array}{c}15.21 \\
(\mathbf{1 6 . 2 0})\end{array}$ & One-step & $50-60$ & This work \\
\hline $\mathrm{CH}_{3} \mathrm{NH}_{3} \mathrm{PbI}_{3}$ & $\begin{array}{c}12.48 \\
(\mathbf{1 4 . 2 5})\end{array}$ & Two-step & 50 & {$[1]$} \\
\hline $\mathrm{CH}_{3} \mathrm{NH}_{3} \mathrm{PbI}_{3}$ & $\begin{array}{c}6.68 \\
(\mathbf{8 . 0 8})\end{array}$ & One-step & $40 \pm 5$ & {$[2]$} \\
\hline $\mathrm{CH}_{3} \mathrm{NH}_{3} \mathrm{PbI}_{3}$ & $(14.66)$ & One-step & $>70$ & {$[3]$} \\
\hline $\mathrm{CH}_{3} \mathrm{NH}_{3} \mathrm{PbI}_{3-\mathrm{x}} \mathrm{Cl}_{\mathrm{x}}$ & $\begin{array}{l}7.63 \\
(9.2)\end{array}$ & One-step & 50 & {$[4]$} \\
\hline $\mathrm{CH}_{3} \mathrm{NH}_{3} \mathrm{PbI}_{3}$ & $\begin{array}{c}12.0 \\
(\mathbf{1 5 . 0})\end{array}$ & One-step & 75 & {$[5]$} \\
\hline$($ FAPbI3)0.85(MAPbBr3)0.15 & $\begin{array}{c}17.6 \\
(\mathbf{1 8 . 8})\end{array}$ & One-step & 50 & {$[6]$} \\
\hline $\mathrm{CH}_{3} \mathrm{NH}_{3} \mathrm{PbI}_{3}$ & $(\mathbf{1 0 . 5 2})$ & One-step & $65-75$ & {$[7]$} \\
\hline $\mathrm{CH}_{3} \mathrm{NH}_{3} \mathrm{PbI}_{3}$ & $\begin{array}{c}13.17 \\
(\mathbf{1 4 . 2 4})\end{array}$ & One-step & 60 & {$[8]$} \\
\hline $\mathrm{CH}_{3} \mathrm{NH}_{3} \mathrm{PbI}_{3}$ & $\begin{array}{c}16.13 \\
(\mathbf{1 7 . 2 4})\end{array}$ & One-step & 40 & {$[9]$} \\
\hline $\mathrm{CH}_{3} \mathrm{NH}_{3} \mathrm{PbI}_{3-\mathrm{x}} \mathrm{Cl}_{x}$ & $(14.0)$ & One-step & 40 & {$[10]$} \\
\hline $\mathrm{CH}_{3} \mathrm{NH}_{3} \mathrm{PbI}_{3}$ & $\begin{array}{c}15.6 \\
(\mathbf{1 6 . 3})\end{array}$ & One-step & $60-70$ & [11] \\
\hline $\mathrm{CH}_{3} \mathrm{NH}_{3} \mathrm{PbI} \mathrm{I}_{3}$ & $\begin{array}{c}13.7 \\
(\mathbf{1 6 . 1})\end{array}$ & One-step & $30-60$ & {$[12]$} \\
\hline $\mathrm{CH}_{3} \mathrm{NH}_{3} \mathrm{PbI}_{3}$ & $\begin{array}{c}12.21 \\
(\mathbf{1 2 . 6 2})\end{array}$ & Two-step & $40-50$ & {$[13]$} \\
\hline $\mathrm{CH}_{3} \mathrm{NH}_{3} \mathrm{PbI}_{3}$ & $\begin{array}{c}16.20 \\
(\mathbf{1 8 . 1 1})\end{array}$ & Two-step & 70 & {$[14]$} \\
\hline $\mathrm{CH}_{3} \mathrm{NH}_{3} \mathrm{PbI}_{3}$ & $(7.19)$ & Two-step & $60-70$ & {$[15]$} \\
\hline $\mathrm{CH}_{3} \mathrm{NH}_{3} \mathrm{PbI}_{3}$ & $\begin{array}{c}8.3 \\
(\mathbf{8 . 3 8})\end{array}$ & Two-step & 60 & [16] \\
\hline Cso.15FA0.85 $\mathrm{PbI} 3$ & $\begin{array}{c}14.21 \\
(\mathbf{1 5 . 5 6})\end{array}$ & Two-step & $70 \pm 10$ & {$[17]$} \\
\hline $\mathrm{CH}_{3} \mathrm{NH}_{3} \mathrm{PbI}_{3}$ & (12) & Electrospray & $30-50$ & {$[18]$} \\
\hline $\mathrm{CH}_{3} \mathrm{NH}_{3} \mathrm{PbI}_{3-\mathrm{x}} \mathrm{Cl}_{x}$ & $\begin{array}{c}11.12 \\
(\mathbf{1 3 . 5 0})\end{array}$ & $\begin{array}{l}\text { Ultrasonic } \\
\text { spray }\end{array}$ & 30 & {$[19]$} \\
\hline $\mathrm{CH}_{3} \mathrm{NH}_{3} \mathrm{PbI}_{3}$ & $\begin{array}{c}12.0 \\
(\mathbf{1 2 . 3})\end{array}$ & Slot-die & 60 & {$[20]$} \\
\hline
\end{tabular}




\section{Reference}

[1] Y. Guo, L. Kang, M. Zhu, Y. Zhang, X. Li, P. Xu, A strategy toward air-stable and high-performance $\mathrm{ZnO}$-based perovskite solar cells fabricated under ambient conditions, Chem. Eng. J. 336 (2018) 732-740. https://doi.org/https://doi.org/10.1016/j.cej.2017.11.189.

[2] S. Prathapani, V. More, S. Bohm, P. Bhargava, A. Yella, S. Mallick, TiO 2 colloidbased compact layers for hybrid lead halide perovskite solar cells, Appl. Mater. Today. 7 (2017) 112-119. https://doi.org/10.1016/j.apmt.2017.01.009.

[3] Y. Yang, T. Chen, D. Pan, J. Gao, C. Zhu, F. Lin, C. Zhou, Q. Tai, S. Xiao, Y. Yuan, Q. Dai, Y. Han, H. Xie, X. Guo, MAPbI3/agarose photoactive composite for highly stable unencapsulated perovskite solar cells in humid environment, Nano Energy. 67 (2020) 104246. https://doi.org/https://doi.org/10.1016/j.nanoen.2019.104246.

[4] G. Wang, D. Liu, J. Xiang, D. Zhou, K. Alameh, B. Ding, Q. Song, Efficient perovskite solar cell fabricated in ambient air using one-step spin-coating, RSC Adv. 6 (2016) 43299-43303. https://doi.org/10.1039/C6RA05893K.

[5] J. Troughton, K. Hooper, T.M. Watson, Humidity resistant fabrication of CH3NH3PbI3 perovskite solar cells and modules, Nano Energy. 39 (2017) 60-68. https://doi.org/10.1016/j.nanoen.2017.06.039.

[6] K. Sveinbjörnsson, K. Aitola, J. Zhang, M.B. Johansson, X. Zhang, J.-P. Correa-Baena, A. Hagfeldt, G. Boschloo, E.M.J. Johansson, Ambient air-processed mixed-ion perovskites for high-efficiency solar cells, J. Mater. Chem. A. 4 (2016) 16536-16545. https://doi.org/10.1039/C6TA06912F.

[7] J. Bahadur, A.H. Ghahremani, B. Martin, T. Druffel, M.K. Sunkara, K. Pal, Solution processed Mo doped $\mathrm{SnO} 2$ as an effective ETL in the fabrication of low temperature planer perovskite solar cell under ambient conditions, Org. Electron. 67 (2019) 159167. https://doi.org/https://doi.org/10.1016/j.orgel.2019.01.027.

[8] K. Huang, C. Wang, C. Zhang, S. Tong, H. Li, B. Liu, Y. Gao, Y. Dong, Y. Gao, Y. Peng, J. Yang, Efficient and stable planar heterojunction perovskite solar cells fabricated under ambient conditions with high humidity, Org. Electron. 55 (2018) 140145. https://doi.org/https://doi.org/10.1016/j.orgel.2018.01.029.

[9] K. Liao, J. Yang, C. Li, T. Li, F. Hao, Off-Stoichiometric Methylammonium Iodide Passivated Large-Grain Perovskite Film in Ambient Air for Efficient Inverted Solar Cells, ACS Appl. Mater. Interfaces. 11 (2019) 39882-39889. https://doi.org/10.1021/acsami.9b12829.

[10] D. Gedamu, I.M. Asuo, D. Benetti, M. Basti, I. Ka, S.G. Cloutier, F. Rosei, R. Nechache, Solvent-Antisolvent Ambient Processed Large Grain Size Perovskite Thin Films for High-Performance Solar Cells, Sci. Rep. 8 (2018) 12885. https://doi.org/10.1038/s41598-018-31184-0.

[11] F. Yang, G. Kapil, P. Zhang, Z. Hu, M.A. Kamarudin, T. Ma, S. Hayase, Dependence of Acetate-Based Antisolvents for High Humidity Fabrication of CH3NH3PbI3 Perovskite Devices in Ambient Atmosphere, ACS Appl. Mater. Interfaces. 10 (2018) 16482-16489. https://doi.org/10.1021/acsami.8b02554.

[12] D. Di Girolamo, F. Matteocci, M. Piccinni, A. Di Carlo, D. Dini, Anodically electrodeposited $\mathrm{NiO}$ nanoflakes as hole selective contact in efficient air processed $\mathrm{p}$-i- 
n perovskite solar cells, Sol. Energy Mater. Sol. Cells. (2019) 110288.

https://doi.org/https://doi.org/10.1016/j.solmat.2019.110288.

[13] C. Liu, W. Ding, X. Zhou, J. Gao, C. Cheng, X. Zhao, B. Xu, Efficient and Stable Perovskite Solar Cells Prepared in Ambient Air Based on Surface-Modified Perovskite Layer, J. Phys. Chem. C. 121 (2017) 6546-6553. https://doi.org/10.1021/acs.jpcc.7b00847.

[14] Y. Cheng, X. Xu, Y. Xie, H.-W. Li, J. Qing, C. Ma, C.-S. Lee, F. So, S.-W. Tsang, $18 \%$ High-Efficiency Air-Processed Perovskite Solar Cells Made in a Humid Atmosphere of 70\% RH, Sol. RRL. (2017) 1700097. https://doi.org/10.1002/solr.201700097.

[15] N. Islavath, S. Saroja, K.S. Reddy, P.C. Harikesh, G. Veerappan, S. V. Joshi, E. Ramasamy, Effect of hole-transporting materials on the photovoltaic performance and stability of all-ambient-processed perovskite solar cells, J. Energy Chem. 26 (2017) 584-591. https://doi.org/10.1016/j.jechem.2016.12.011.

[16] G. Murugadoss, H. Kanda, S. Tanaka, H. Nishino, S. Ito, H. Imahoric, T. Umeyama, An efficient electron transport material of tin oxide for planar structure perovskite solar cells, J. Power Sources. 307 (2016) 891-897. https://doi.org/10.1016/j.jpowsour.2016.01.044.

[17] X. Xu, C. Ma, Y.-M. Xie, Y. Cheng, Y. Tian, M. Li, Y. Ma, C.-S. Lee, S.-W. Tsang, Air-processed mixed-cation $\mathrm{Cs} 0.15 \mathrm{FA} 0.85 \mathrm{PbI} 3$ planar perovskite solar cells derived from a PbI2-CsI-FAI intermediate complex, J. Mater. Chem. A. 6 (2018) 7731-7740. https://doi.org/10.1039/C8TA01049H.

[18] S. Kavadiya, D.M. Niedzwiedzki, S. Huang, P. Biswas, Electrospray-Assisted Fabrication of Moisture-Resistant and Highly Stable Perovskite Solar Cells at Ambient Conditions, Adv. Energy Mater. 7 (2017) 1700210. https://doi.org/10.1002/aenm.201700210.

[19] J. Su, H. Cai, X. Ye, X. Zhou, J. Yang, D. Wang, J. Ni, J. Li, J. Zhang, Efficient Perovskite Solar Cells Prepared by Hot Air Blowing to Ultrasonic Spraying in Ambient Air, ACS Appl. Mater. Interfaces. 11 (2019) 10689-10696. https://doi.org/10.1021/acsami.9b01843.

[20] Y.-C. Huang, C.-F. Li, Z.-H. Huang, P.-H. Liu, C.-S. Tsao, Rapid and sheet-to-sheet slot-die coating manufacture of highly efficient perovskite solar cells processed under ambient air, Sol. Energy. 177 (2019) 255-261.

https://doi.org/https://doi.org/10.1016/j.solener.2018.11.020. 